\title{
Comments
}

\section{LAKE TAHOE: THE FUTURE OF A NATIONAL ASSET- LAND USE, WATER, AND POLLUTION}

In Roughing $I t$, Mark Twain wrote of Lake Tahoe: "As it lay there with the shadows of the mountains brilliantly photographed upon its still surface I thought it must surely be the rarest picture the whole earth affords." Since its discovery in 1844 by John C. Fremont, Lake Tahoe's natural beauty and the surrounding area's scenic attraction have been praised by both permanent residents and an increasing flood of tourists. ${ }^{1}$ Situated geographically in a climate which makes possible year-round use as a recreation center, it lies within a four hour drive of some three milhon people and scarcely niore than one day's drive of nearly ten percent of the total population of the United States. ${ }^{2}$

Lake Tahoe is currently the focus of other attention than that given by the 1964 summer tourists. There exist three overlapping problems which must be resolved if the unique physical characteristics of the area are to be preserved and if maximum effective utilization is to be made of the large volunie of water originating at Tahoe. Land use must be regulated with concern for both preservation and development interests; water must be allocated according to the rights and the present and future needs of lake and downstream users; and pollution must be controlled to preserve liealth and aesthetic conditions. In the past decade much of the action of federal, state, and local pubhic agencies and private groups in governing the Lake Talioe area has been ineffective. It is the purpose of this Comment to analyze these three problems, to examine the governing bodies and their limitations, and to consider means to remedy their insufficiencies.

I

THE NATURE OF THE AREA

Lake Tahoe lies in a basin completely surrounded by mountain ranges reacling elevations of more than 10,000 feet-the Sierra Nevada

1 Mark Twain spent considerable time in the Lake Tahoe-Virginia City area and served as editor of Virgimia City's Territorial Enterprise. In that newspaper he wrote frequently of Lake Tahoe, its people and events. RougHnNG IT, published by Harpers in 1871, is replete with descriptions of the lake and anecdotes about its noteworthy characters. In one picturesque phrase he describes the mountain air as follows: "The air up there in the clouds is very pure and fine, bracing and delicious. And why shouldn't it be?-it is the same the angels breathe." Tahoe received much attention in the writings of John Muir. It has been the subject of numerous books including Tre SAga of Lake TaHoe by E. B. Scott and Sterra-Nevada lakes by George and Bliss Hinkle.

2 Engrneering-Sctence, Inc., Comprehensive Stgud on Protection of Water Resources of lake Tafoe Bastn Through Controllen Waste Disposal, Prepared for lake Tamoe Area Councti (1963) [hereinafter cited as Compremensive Study]. 
on the west and the Carson range on the east. The basin is 511 square miles; the surface area of the lake itself is 193 square miles. ${ }^{8}$ Approximately seventy percent of the basin is in California and thirty percent in Nevada. Tahoe lias seventy miles of shoreline; sixty percent of that is in Califorma and the remainder in Nevada. On the California side the northern half of the basin is in Placer County and the southern lialf in El Dorado County. 4 On the Nevada side the northern portion is in Washoe County, the central in Ormsby, and the southern in Douglas County. Approximately fifty percent of the land in the basin is owned by the United States. ${ }^{5}$

The lake itself is the largest alpine lake in the world from the standpoint of dimensions, depth, and volume of water impounded. ${ }^{6}$ It is a vast marine amphitheatre averaging 980 feet in depth, including all shallows and bays. Its perpendicular drop-offs occur so suddenly that a boat may be in twenty-five feet of water one moment and 1,400 feet the next. The water is famed for its crystal clarity, and this crystalline quality combines with the great depth to give Tahoe a royal blue color. The sole source of water for Tahoe is the melting snow of the surrounding basin. The Truckee River which originates at Tahoe City, California, on the northwestern side of the lake is the only outlet. The Truckee is additionally fed by small tributaries, and flows for 115 miles in a generally northern and eastern direction into Nevada, through Reno, terminating at Pyramid Lake.

The first Lake Tahoe bonanza was lumber. During the Virginia City, Comstock days, Tahoe was the chief source of lumber for the booming silver mining industry. The penalty for the lumbering of the 1870's and 1880's was heavy. The basin was denuded of liundreds of thousands of acres of virgin pine and fir; almost all timber in the basin today is second growth. Tahoe is now in the midst of a second bonanza-tourism. The area presents a unique recreational combination of water, mountain, and winter recreation plus the excitement of Nevada gaming and big-

\footnotetext{
3 Statistics on land area within the Lake Tahoe basin are taken from a report and analysis of the demographic, economic, geographic and financial aspects of the Lake Tahoe basin and surrounding areas, prepared for Universal Inc., Las Vegas, Nevada, by Raymond M. Smith A.I.P., Planning Consultant, Reno and Lake Tahoe (1963).

4 A small portion of the Lake Tahoe basin is located in Alpine County, Cahifornia. This portion, less than 10 square miles, is located at some distance from the lake, and is not part of the area currently being developed. Therefore, it will receive no consideration in this Coinment. See Wirsey, HaM \& BIATR, MmlbraE, Calmornia-Consuitants, Preiminary Regtonal Plan, Lake Tahoe 1980 Regional Plan Program (1961) [hereinafter cited as Premmanary Recionar Plan].

5 Forest Service Regtows 4 and 5, U.S. Departament of Agruculture, Multiple Use Management Plan for Natyonac Forest Lands, Laze Tahoe Basn 1 (1962).

6 ScotT, The Saga of Lake Tagoe 460 (1957).
} 
name entertainment. The estimated number of residents during the summer months-including both permanent and summer-only residents-has grown from 9,500 in 1956 to 27,100 in 1962 , and that figure is expected to reach 80,000 by $1980 .{ }^{7}$ If the number of transient tourists in the basin at any time during the summer season is included in the computation, the total population has risen from 36,400 in 1956 , to 126,300 in 1962; it is predicted to reach 418,000 by $1980 .{ }^{8}$

The geographical location of Lake Tahoe and the pattern of land ownership in the basin have contributed greatly to the complex myriad of agencies exercising some form of jurisdiction. Because the lake is located both in California and Nevada, there are corresponding agencies of each state exercising jurisdiction in the basin. ${ }^{9}$ Each of the five Lake Tahoe counties has a governing body exercising local governmental functions. In addition, each county has established agencies to cope with special county problems. ${ }^{10}$ There are a number of special districts dealing with such matters as schools, sewage disposal, and fire fighting. The U.S. Forest Service manages land in three separate national forests: Tahoe and El Dorado on the California side and Toiyabe on the Nevada side. Although this hist of agencies is far from complete, their complex interrelationship can be appreciated when it is realized that all operate within an integrated area of only 511 square miles. There are also a number of private organizations exerting varying degrees of impact upon the basin, particularly in the area of water supply.

II

THE LAND USE PROBLEM

\section{A. Local Agency Regulation of Private Land Use}

A statement of the general pattern of land use in the Lake Tahoe basin will introduce the problems which exist as to land utilization regulation. Land development clearly reflects that tourism is the principal industry. ${ }^{11}$ Streets account for alnost fifty percent of all developed

7 Wissey, Haxr \& Blair, Mtrlbrae, Californta-Consurtants, Technicax Supplement, Prelimmary Plan Report, Lake Tamoe 1980 Regional Plan Program 6.23 (1961) [hereinafter cited as TeCHNICAL SUPPLEMENT].

8 Id. at 6.29 .

9 By way of illustration, there are two state divisions of forestry, of parks and recreation, of highways, of pubhic health, of natural resources, of fish and game.

10 For example, there are five county planning commissions and five county health departments.

11 Percentage breakdown of uses of all developed land in the basin is as follows: streets $46.3 \%$, housing $32 \%$, motels $6.2 \%$, parks $6.2 \%$, retail $3 \%$, schools $1.6 \%$, utilities $1.4 \%$, public $1.3 \%$, industry $1.2 \%$, offices $0.4 \%$, gaming $0.3 \%$. Tecrndeat Supplemenent $2.21(\mathrm{~b})$. 
land, ${ }^{12}$ with another forty-four percent devoted to housing, motels, and parks. ${ }^{13}$ The south shore leads all other areas with approximately seventyone percent of the permanent population. ${ }^{14}$ This is due in part to the location of gambling casinos at Stateline and in part to the favorable terrain there. ${ }^{15}$ The north shore follows with approximately nineteen percent of the permanent population..$^{16}$ Along the west shore, between Carnelian Bay at the north and Emerald Bay at the south, summer residences and resorts predominate. ${ }^{17}$ Development on the east shore has been very sparse. ${ }^{18}$

El Dorado, Placer, Douglas, and Washoe Counties have attempted to control land use within their respective counties in the Tahoe area by the use of zoning laws. ${ }^{19}$ The scheme of each zoning law is similar. Various classifications of residential, commercial, and industrial uses are designated, and maps are incorporated, indicating which classification applies to each area of land. Permissible uses within each classification are

12 See note 11 supra.

13 See note 11 supra.

14 Techntcal Supplearent 6.15(a).

15 The two biggest gaming clubs are located at Stateline and serve as year-round attractions for gamblers from all parts of Northern California. Buses from the San Francisco and Sacramento areas arrive daily. The geograplyy of the area is particularly suited to the muslrooming development which started to occur in the 1950's. Talioe Valley extends for several miles at the south end of Taloe, constituting the largest area of flat land in the basin. Highway 50 leads from Sacramento and Placerville to the southwest corner of the lake and proceeds around the south shore to the Nevada State Line. It is along this highway that the bulk of all coinmercial development has occurred.

16 TeCHNical SUPpLEMENT 6.15(a). The pattern of growth at the north shore has been similar to that of the south end of Tahoe, but on a smaller scale. Several year-round casinos are located at Crystal Bay. On the California side a commercial zone has grown along highway 28 at Kings Beach.

17 The lake front land between these two points, with a few exceptions, is owned entirely by private parties. The bulk consists of large summer estates. Some land is held by resorts, and there are several marinas. The west shore has grown very slowly. It is served commercially by Tahoe City, located at the outlet to the Truckee River. Recent expansion at Tahoe City appears attributable to the increasing popularity of the area as a winter sports haven since the Winter Olympics at nearby Squaw Valley in 1960. Only 9.6\% of the permanent population is located along the west shore. TECrnical SuppLEMrent $6.15(a)$.

18 This is due in part to the pattern of land ownership on that side of the lake and in part to the steep terrain. The land from Crystal Bay to Dead Man's Point, comprising approximately one-half the entire eastern shore, was owned by George Whittell of San Francisco until its recent sale. This property includes the land currently under consideration for a Nevada state park. See note 74 infra and accompanying text. The balance of the east sliore is either undeveloped or used as residential or resort property. The residential areas extend from Zephyr Cove soutl to the state hine, and population in that area is included in the $71 \%$ figure indieated for the south slore.

19 See Ex Dorado County, Cad., Code $\S \S 9410-30$; Placer County, Cax., Ordinance 108, Series B; Dougzas County, Nev., Ordinance 121; Washoe County, Nev., OrdiNANCE 57. 
stated. In addition, lot size and building requirements are provided. Each ordinance provides a system for granting adjustments, special use permits, or variances to authorize uses not conforming to the ordinances. ${ }^{20}$ The zoning laws are enforced through the issuance or denial of subdivision and building permits. In addition, there are criminal sanctions for wilful violations.

A visitor to Lake Tahoe need only drive around the lake to see that the county zoning ordinances have not effectively controlled land utihzation. Because of the unusual combination of activities, there may be considerable disagreement as to the best restrictions to impose in order to protect Lake Tahoe as a national resource. There are, however, at least minimum points on which any visitor would agree. Tahoe is a spectacular mountain area of unique recreational opportunities and magnificent scenic attractions which happens to be located partly in Nevada where gambhing is legalized, not just a gaming center wlich liappens to be located in a specially desirable physical setting. ${ }^{21}$ Development of a gambling and entertainment strip similar to those of Las Vegas and Reno is inappropriate and would prostitute Tahoe's natural assets. ${ }^{22}$ Carnivals, hot dog stands, used-car lots, junk yards, flashy neon signs, and high-rise structures are equally unsuitable, yet each is either possible, or already exists, in one or more of the counties. Deficiencies at the county level are two-pronged: (1) the ordinances themselves have not been bold enough in restricting permissible uses; and (2) there have been significant departures from even the minimum limitations.

20 There is considerable variation in the methods provided for granting adjustments, special use permits, and variances. Traditionally a non-conforming use is a use that existed prior to adoption of the ordinance. A conditional use permit is granted to authorize an otherwise prohibited use when it is shown to be essential or desirable to the public convenience; hardship is not a prerequisite. The essential requirement for granting a variance is a showing that strict enforcement would cause unnecessary hardship. See generally Tustin Heights Ass'n v. Board of Supervisors, 170 Cal. App. 2d 619, 339 P.2d 914 (1959). The ordinances of the five Tahoe counties have not adopted the classical procedures and titles with respect to techmiques of granting variances. For example, Placer County does not bar unlimited continuance of non-conforming uses unless they are discontinued for over one year and then resumed. Placer County, Car., Ordnance 108, Series $B, \S 9.1$. The ordinance provides a single technique, the adjustment, to handle what might classically be considered a conditional use permit or variance. Id. $\$ 11$.

21 See Taboe Daily Tribune, Jan. 27, 1964, p. 1, col. 7.

22 It is true that many people visit the Tahoe area solely to gamble. In a recent survey of visitors, $38.5 \%$ indicated tbat gaming was a motivation bringing them to the lake. The pollsters concluded that even when adjusted to $50 \%$ in order to account for permanent residents polled, the figure underestimates the gaming appeal because the sampling was of tourists with private cars. Those arriving by public transportation are more likely to be gambling-oriented. TECHNICAI. SUPPLEMENT 6.50-.51.

It is not suggested that Nevada should be asked to abolish gaming at Lake Tahoe. It is urged that gambling be restricted to prevent growth of cities of plush, high-rise entertainment facilities which are more suited to areas such as Las Vegas and Reno. 
Construction of the multi-storied Harvey's Wagon Wheel Resort Hotel and Casino dramatizes the lack of adequate height controls. This green and orange structure rises ten floors above a ground level casino and is topped by a huge neon sign in red and black emphasizing the skull of a dead steer. Although the building might be appropriate in Reno, at Tahoe it devastates the landscape. ${ }^{23}$ The building is located at Stateline, Douglas County, Nevada, in an area zoned as a general commercial district. Douglas County imposes no height himitations whatsoever on buildings in such districts. ${ }^{24}$ Furthermore, this general commercial zone extends for some distance from the Nevada state line on either side of highway 50 , thereby enabling the construction of more high-rise structures in the future. ${ }^{25}$ Plans of several builders to proceed with similar buildings are already in advanced stages. ${ }^{26}$ Washoe County, Nevada, also has a number of areas zoned for general commercial use which are subject to no height limitations. ${ }^{27}$

The pattern of commercialization at Tahoe resembles a ribbon circumscribing the lake shore. This problem is particularly evident at the south shore where business activity continues for many miles along highway 50, but is almost never deeper than one block. The result is a congestion of around-the-lake travelers and local traffic. A visitor is also given the impression that urban development in the area is progressing even more rapidly than is in fact the case. The clustering of commercial zones would not only improve their efficiency, but would also leave more of the scenery along the highways in its natural condition. The zoning ordinances of both California counties, however, have adopted these ribbon-like commercial zones. ${ }^{28}$

A very wide range of uses is permitted in commercial zones. For example, the Placer County ordinance lists a number of permissible uses and then adds, "Any other use that does not emit or cause objectionable odor, dust, noise, smoke or vibration."29 This clause apparently allows hot dog and taco stands, frontier villages, miniature golf courses, and other activities which make Kings Beach look like San Francisco's Playland-

23 Indeed, its huge size assures its visibility from any point on the lake.

24 Douglas County, Nev., Ordinance 121, art. 25.

25 See map of Douglas County, Nev., Planning Counmission incorporated in Dougras Countx, Nev., OrdTnance 121.

26 Tahoe Daily Tribune, Oct. 7, 1963, p. 1, col. 2.

27 Washoe County, Nev., Ordinance 57, art. 20 C. See Map, Land Use Plan-District No. 2 for areas zoned for commercial use.

28 See Placer County, Cal., Official Map Adopted as Part of Ordinance 108 for illustration of ribbon-like commercial zones.

20 Placer County, Cax., Ordinance 108, Series B, \& 6.1(4). 
at-the-Beach. ${ }^{30}$ The south shore in El Dorado County is even more honky-tonk. In addition to uses similar to those in Kings Beach, the Tahoe Valley "Y" now boasts a carnival. ${ }^{31}$ All such uses are permissible under the liberal restrictions of the El Dorado County regulations for commercial zones. ${ }^{32}$ Permissible activities in Douglas County commercial zones are equally numerous, ${ }^{33}$ but as yet the area remains relatively undeveloped. ${ }^{34}$ Washoe County is the most lemient of the four. Part of Incline Village at Crystal Bay is zoned for industrial use. ${ }^{35}$ Under that classification manufacturing, processing, assembly, and fabrication are allowed. $^{36}$ The Crystal Bay Development Company will in no way be restricted by Washoe County zoning laws in effecting its plans to turn that area into a city. ${ }^{37}$ Building is already in progress to that end.

Although restrictions imposed upon private landowners by the zoning ordinances are mimimal when considered with regard to protection of the basin's physical attributes, nevertheless, maintenance of even the low level of protection sought by planners has eluded the counties. Placer County was the first to apply zoning controls in the Tahoe area. ${ }^{88}$ In the early years of the ordinance's life, enforcement was almost nonexistent. ${ }^{39}$ Signs have presented a particularly troublesome problem. During the 1940's and early 1950's a number of Tahoe merchants erected signs larger than those permitted by the ordinance. The Planning Commission now feels considerable trepidation at denying a request for an adjustment for a new sign, for the party seeking it can point to sigus on both sides of his property that are larger than the sign he proposes to build. The end result is that almost no sign conforms to the requirements of the law. ${ }^{40}$

In El Dorado County, continual conflict between county planners

30 Each of the listed activities is presently being conducted in the Placer County portion of Lake Tahoe.

31 The carnival was installed during the summer of 1963 and survived even the impassioned pleas of El Dorado County supervisors for removal. Tahoe Daily Tribune, July 23, 1963, p. 1, col. 6 .

32 See El Dorado County, CaL., Code § 9413 (a).

33 Permissible activities include light manufacturing and assembly incident to retail sales, wholesale busimesses, used car lots, and unlimited billboards. Dougcas CounTY, NEv., ORDINANCE 121, art. 25.

34 The notable exception is the gambling area at Stateline, to date devoted primarily to casinos, hotels and motels.

35 Washoe County, Nev., Land Use Plan-District No. 2, sheet 3.

36 Washoe County, Nev., Ordinance 57, art. 21(A)(2).

- 37 For a discussion of plans of the Crystal Bay Development $\mathrm{Co}_{0}$, see notes 54-55 infra and accompanying text.

38 Placer County adopted its ordinance in 1940.

30 Interview with Director of Planning Commission, Placer County, Cal, in Auburn, Cal., Sept., 1963.

${ }_{40}$ Almost 50\% of all variances granted in Placer County, Cal. are for signs. Ibid. 
and the supervisors has hamstrung efforts to preserve Lake Tahoe. Variances have been granted with alarming frequency for uses not conforming to the ordinance despite unanimous recommendations to the contrary by the Department of Planning. ${ }^{41}$ In 1963 the fight between planners and supervisors canie to a head when the supervisors fired Paul Brace, Director of the Department of Planning. From a planning standpoint this appears to have been a questionable move, for under Mr. Brace, El Dorado County planning had made significant headway toward preserving the Tahoe area. ${ }^{42}$

Although Ormsby County has a zoning ordinance, as of the end of 1963, it had not been applied to the Lake Tahoe portion of the county.43 For many years George Whittell owned all Tahoe property in Ormsby County, and zoning was thought unnecessary. However, in 1963, Mr. Whittell sold his property to a group of California pronıters. Development of all land that is not purchased for the new state park ${ }^{44}$ may be imminent. The opening of a totally undeveloped area presents Ormsby County planners with a unique opportunity to adopt bold restrictions on permissible uses of private land, but the time when such a plan can be adopted and effectuated will pass quickly as development begins.

The counties' inability to preserve Lake Tahoe as a natural resource is partly because geography makes unsuitable their exercise of jurisdiction in the basin. The two California counties, Placer and El Dorado, extend from the Nevada state line west to the Sacraniento Valley. While Tahoe lies to the east of the crest of the Sierra, the population centers of Placer and El Dorado Counties are considerably to the west. Auburn and Placerville, the respective county seats, are located in the foothills almost 100 miles from Lake Tahoe and serve as centers for the agricultural, lumbering, and ranching activity of the eastern Sacramento

\footnotetext{
41 Interview with Director of Department of Planning, El Dorado County, Cal., in Placerville, Cal., Oct., 1963.

42 More was achieved under the years of Mr. Brace's directorship than in all previous years combined. Although El Dorado County's zoning ordinance was adopted in 1949, by 1957 only 6,500 acres of the county were in precise zones. By 1963 a total of 744,320 acres out of $1,097,190$ acres of land in the county were in precise zones. In addition, a complete new zoning ordinance was prepared for adoption in 1963. Extensive long-range planning for the Tahoe basin hecame an important activity of the department. The firing of Mr. Brace caught the department by surprise and clouded the future of the many unfinished projects he had undertaken. Following a stinging criticism by the El Dorado County Grand Jury of the lack of cooperation between the two agencies and particularly of the firing of Mr. Brace, the Board of Supervisors took immediate action to find a qualified replacement and otherwise strengthen the Commission. Tahoe Daily Tribune, Mar. 3, 1964, p. 1, col. 6 .

43 Interview with Ormsby County, Nev., Planning Commission employee, in Carson City, Nev., Oct. 1963.

44 See note 73 infra and accompanying text.
} 
Valley and the foothills. By way of illustration, only three percent of the registered voters of Placer County live in the Lake Tahoe basin; on the other liand, twenty-three percent of the assessed property for purposes of school taxes is located in the Tahoe basin. ${ }^{45}$ In El Dorado County twenty percent of the registered voters live in the Tahoe area while fifty-four percent of the assessed property of the county for school tax purposes is located there. ${ }^{40}$

The counties on the Nevada side of Tahoe are no better situated to exercise jurisdiction in the basin. The county seat and population center of Waslroe County is Reno, second largest city in Nevada. Tahoe residents comprise less than three percent of the registered voters of Washoe County, and less than one percent of the assessed property of the county is located in the basin. ${ }^{47}$ The entire Talroe portion of Ormsby County is owned by a single interest and contains fewer than ten permanent residents. ${ }^{48}$ The center of Ormsby County's population, Carson City, the county seat and also the Nevada state capital, is located on the eastern side of the Carson range at the liead of the Carson Valley. Douglas County is also split sharply by the Carson range with approximately one-half the population and assessed property at the Lake and the other half in the flat lands around Minden, the county seat, and Gardnerville. ${ }^{49}$

It should be readily apparent that the Lake Tahoe basin does not fit into any one of these counties as part of a cohesive unit. A potential danger is that politicians somewhat removed from Tahoe may be tempted to capitahize on Tahoe's tax base. One of the greatest weaknesses of present county zoning in the basin is its underlying aim-to regulate so long as nothing is done to stop tourists from coming to Tahoe. Increased development leads to increased business and the county treasuries are filled. While this type of planning may be better than none at all, it falls far short of what is needed to preserve the magnificent natural asset that is Lake Tahoe.

Much of the blame for the inadequacies of county efforts must go to permanent residents of Tahoe. These are the people who build and run the carnivals and lot dog stands. These are the people who build higli-rise

45718 of 22,989 registered voters. Statement of Votes Cast, General Election Nov. 6, 1962, Placer County, Cal. $\$ 33,670,710$ of $\$ 147,391,065$ of assessed property. Placer County, Cal., Auditor, 1962 Total Valuation of Placer County School Districts.

46 2,364 of 11,873 registered voters. General Election, Nov. 6, 1962, El Dorado County, Cal., $\$ 59,359,860$ of $\$ 112,054,200$ assessed property. El Dorado School District Valuation of Property, 1963, El Dorado County, Cal.

47175 of 33,928 registered voters. Oct. 15, 1963, Register To Vote Enrollment, Washoe County, Nev. $\$ 5,283,115$ of $\$ 239,702,254$ assessed property. Washoe County, Nev., 1963.

48 Technical Supprement 6.51(a).

49897 of 2,352 registered voters. General Election, Nov. 6, 1962, Douglas County, Nev. $\$ 9,106,839$ of $\$ 18,980,024$ assessed property. Douglas County, Nev. 
hotels. These are the people who fight for the right to erect flashy neon signs. "Sure, I fight to get my sign up." said one operator of a string of snack stands. "But I know the planning commissions are really right. They're trying to do the right thing. We've got to have planning, but at least I'm going to try to argue with them when it comes to my property."

It is true that some permanent residents of the area are making significant contributions for preservation of Lake Tahoe. Of primary importance is the work of a private organization called the Lake Tahoe Area Council. The Council has been working toward regional planning in the Tahoe basin for several years. It has undertaken many important pubhic service projects, including publication of a comprehensive sewageengineering study of Lake Tahoe, ${ }^{51}$ and publication of a series of topical reports dealing with problems of special urgency to the area.

\section{B. U.S. Forest Service-Control of Land Use Through Ownership of Land}

The great bulk of land under control of the Forest Service is at the southern end of the basin in El Dorado National Forest. A map of the Tahoe National Forest resembles a checkerboard, the result of granting alternate sections of land to the Central Pacific Railroad when the first transcontinental railroad was built across Donner Summit. These alternate sections devolved to Southern Pacific Company and later to many private interests. The land of Toiyabe National Forest on the Nevada side is located chiefly in the steep mountain areas of Mount Rose and Slide Mountain to the north, Spooner Summit in the east, and Genoa and Monument Peaks to the south. Because of the steepness and inaccessibility of this land, there is little chance of immediate development.

The conservation aims of the Forest Service have ideally suited that agency to act as prime preserver of the area's natural resources. The ownership of the land, of course, gives that agency a stronger control over its use than is available to agencies which can only regulate the use of land held by others.

A number of policies of the Forest Service have maximized the protection of the basin's natural resources while, at the same time, opening areas to particular kinds of recreational use. Along the south end of Tahoe three miles of national forest beaches have been opened to the public. The rugged splendor of the high country at the southwest end of the basin has been preserved by the creation of Desolation Valley Primitive Area. The Forest Service has instituted a program of land for land ex-

50 Roloff, Trouble at Tahoe, in SAN Francisco 46 (1963).

51 See note 218 infra and accompanying text. 
changes to consolidate its back country loldings by giving up land in the heavily developed Tahoe Valley area of south shore.

A system of special use permits has been designed to allow private parties to participate, under strict controls, in development of Forest Service lands. This device was used in the 1950's to allow construction of summer residences on designated tracts. ${ }^{62}$ Special use permits, however, have not been restricted to summer residences. For example, the South Tahoe Public Utilities District currently sprays treated sewage effluent over 144 acres of Forest Service land at the south end of the basin..$^{53}$ Sale of timber in the national forests has been handled through the use of timber sale contracts. These contracts specifically designate the extent to which lumbering is to be allowed and provide certain reforestation requirements.

In 1962, the United States Department of Agriculture adopted a Multiple Use Management Plan for National Forest Lands in the Lake Tahoe Basin. Its stated intention is to intensify management of public lands in the basin to assure optimum use. The plan promulgates general instructions for the operation of these lands, and appears to offer direction for the maximum long-range use of natural resources of the Tahoe basin by the maximum number of people. Chances for success of the program appear particularly good in El Dorado National Forest where property holdings are consolidated. The checkerboard holdings in the Tahoe National Forest reduce the effectiveness of any overall planning. It is doubtful if any significant accomplishments can be made with the widely scattered holdings of Toiyabe National Forest.

\section{Private Regulation of Land Utilization}

The new development at Incline Village located at Crystal Bay, Nevada, at the north end of Lake Tahoe, introduces the concept of private regulation of land utilization. Property for the new project was acquired by the Crystal Bay Development Company from part of the vast lioldings of George Whittell. Planners for the Company have devised a lot-by-lot scheme for development of an entire commnnity. ${ }^{54}$ The plan rejects the

52 Forest Service summer residence tracts are located at Emerald Bay, Blackwood Creek, Carnelian Bay, and Kings Beach around the lake. Tracts are also located on the Truckee River and at Echo and Fallen Leaf Lakes.

63 Treated sewage is sprayed over national forest lands under Term Special Use Permit \#2710, granted Aug. 23, 1963, by the El Dorado National Forest Service. An injunction was unsuccessfully sought against this controversial method of effluent disposal by the Kyburz family, owners of a large piece of adjoining property, on grounds that such disposal constituted a nuisance.

54 Their plans include development of a core commercial center with numerous hotels and multiple residences, shopping centers, and a hospital. The core of the central area is designated for "heavy commercial" activity. The perimeter is to consist of residential areas. 
Tahoe tradition of commercial zones ribboning the highway and clusters the commercial zone in the center of the community, away from through highways. The scheme is to be effectuated by restrictive covenants running with each lot. ${ }^{55}$

Efforts of the Crystal Bay Development Company to achieve a planned community are commendable. Nevertheless, the springing up of a large community including commercial areas and numerous hotels may not preserve the area as a natural asset. It is too soon to tell how extensive unsuitable commercialization in the area will be. The company has been successful in achieving very liberal zoning laws in the area, ${ }^{50}$ thereby opeming the door to unlimited development-and possible desecration of the previously unspoiled beauty of the Crystal Bay area.

\section{Regional Planning}

Several agencies have been working for solution of Lake Talioe problems at the regional level. Reference has already been made to the Multiple Use Management Plan for National Forest Lands in the Lake Tahoe Basin, ${ }^{57}$ and the Lake Tahoe Area Council. ${ }^{68}$ Work of the California-Nevada Interstate Compact Commission will be described subsequently. ${ }^{58}$ Several agencies deal with a single problem of land use at the regional level.

One such agency is the California Division of Highways, responsible for all highway planning on the California side of the lake. ${ }^{66}$ It is beyond the scope of this comment to analyze the operations of that much-maligned agency. At Tahoe, as in many other parts of California, the division has been subjected to severe criticism for planning freeways through outstanding scenic areas with regard chiefly for mimimizing costs and speeding the flow of traffic. ${ }^{61}$ The question of how to construct an all-year highway througl the Enierald Bay area is the source of more controversy than any other single issue. ${ }^{2}$ In general, the division of higliways and

55 The restrictions cover such subjects as the type of buildings that may be constructed, requirements of committee approval for plans, permissible activities on property, garbage disposal, raising of arimals, and placing of signs.

50 See text accompanying notes $35-37$ supra.

57 See text following note 53 supra.

58 See text accompanying note 51 supra.

59 See notes 147-97 infra and accompanying text.

60 Lake Tahoe is in District III of the Cahfornia Division of Highways with headquarters in Marysville, Cal.

61 San Francisco Chronicle, Sept. 7, 1963, p. 1, col. 2. A committee of irate west shore residents has recently been formed to carry the fight against the division of highways to the state legislature, the governor, and the federal government. Id., Jun. 28, 1964, p. 1, col. 6; May 21, 1964, p. 1, col. 7.

62 The present road around Emerald Bay on the west side of Tahoe has a bad shide area, 
permanent residents favor a bridge across Emerald Bay because it would be cheaper and shorten the drive around the lake. ${ }^{63}$ On the other hand, tourists, summer residents, and the California Division of Beaclies and Parks oppose any bridge. ${ }^{64}$

The Emerald Bay bridge dispute has obscured the much larger issue of what type of highway is needed around the west shore of Tahoe. Traffic flow predictions may well justify the building of a freeway, but such a consideration should not be allowed to overshadow the public interest in maintaining the west shore in its unsullied state. It has been pointed out that vacationers to the Tahoe area traveling the west shore are not in a hurry to get anywhere as the highway is not part of a through route to or from the Tahoe area. ${ }^{65}$ Planners liave predicted that a twolane scenic parkway will adequately serve traffic needs through $1980 .{ }^{66}$ The division of highways is currently adopting a route for the proposed highway, and has not yet determined the size of the road to be built. The possibitity, however, of constructing at least four lanes is under consideration. ${ }^{67}$ Thus, the power of an autonomous state agency dealing solely with highways poses a serious threat to the preservation of Tahoe, for the decisions of the highway engineers will do much to shape the area's landscape.

Another single-purpose agency is the California-Nevada Interstate Park Commission, which was created to work toward acquisition and development of a bi-state park within the Tahoe basin. At the present time only two state parks of any size are owned by either state-Bliss and Emerald Bay. Only seven of the lake's seventy miles of shoreline are in public ownership. ${ }^{68} \mathrm{~A}$ recent survey questioned visitors as to deficiencies of the Tahoe area. Twenty-one percent of those questioned complained of a slortage of various sunimer outdoor recreation facilities. The most frequently mentioned shortage was swimming beaches, followed by picnic areas and forest parks. ${ }^{69}$ State ownership of Tahoe land as a park appears to offer the best possible method of conserving the basin.

is extremely narrow, and contains many sharp curves. In winter, permanent residents who want to get to or from the south shore have to bypass Emerald Bay, for the highway cannot be kept open. Drivers who service the Cabifornia side must drive completely around the lake to make their deliveries.

63 Roloff, supra note 50.

64 The building of a bridge across Emerald Bay would not only destroy the natural beauty of that magnificent, fjord-like inlet, but also necessitate approach highways cutting a path through two spectacular state parks.

65 Roloff, supra note 50.

66 See Premtarnarary Regional Plan.

67 San Francisco Chronicle, Jan. 24, 1964, p. 5, col. 1.

68 Technicai Supplearent 4.3.

60 Id. at 6.51 . 
At the time the Interstate Park Commission was created, a huge block of land on the east shore was offered for sale by George Whittell. This land included nine miles of shorehne and was the last substantial piece of undeveloped property at Tahoe. A unique opportunity for the preservation of such a vast part of Lake Tahoe was visualized by proponents of the bi-state park. ${ }^{70}$ The high cost of this property ${ }^{71}$ and the potentially large number of Califorma users made the bi-state approach desirable, although the land was located entirely in Nevada.

The bi-state approach to a park, however, was killed by the Nevada legislature. The main objection to a joint approach appeared to be a fear by Nevada legislators that if Cahifornia put up a large percentage of the money, California officials would obtain unwarranted leverage in administration of the park located on Nevada's own soil. ${ }^{72}$ There was also considerable reluctance to remove from the tax rolls so much land which could be developed. ${ }^{73}$ At a special session in February, 1964, Nevada decided to create a smaller park without participation by California. ${ }^{74}$

Failure of efforts to produce a bi-state park illustrate the inability of Cahfornia and Nevada to cooperate even at top levels in joint solution of Tahoe problems. Nevertheless, a serious attempt is currently under way to work for area-wide planning studies and controls. This effort is under the direction of the recently formed Tahoe Regional Planning Commission, composed of representatives of each of the five Tahoe counties and each of the two states. The commission has no official jurisdiction, but considerable interest and optimism has attended its work. It procured the services of consultants to prepare a master plan for the Tahoe area. The first step was preparation of a prehiminary regional plan through the assistance of a federal grant fronı the Urban Renewal Administration of the Housing and Home Finance Agency. A prehiminary report of work to November, 1961, has been completed. Release of the final Lake Tahoe Regional Plan is expected in 1964. The plan adopts 1980 as the target year and proposes to guide the entire physical development of the basin through the target year. Objectives of the plan include determining the best use of land, preventing misuse, waste, and premature development of land, and promoting a diversified balance of living, employment, recreation, and cultural opportunities. The plan deals with such topics as

${ }^{70}$ They urged the purchase of Whittell property and the consolidation of current Nevada-owned property at Marlette Reservoir and United States Forest Service lands to form a park in excess of 25,000 acres.

71 It was believed the property might cost $\$ 15,000,000$.

72 Tahoe Daily Tribune, Jan. 24, 1964, p. 1, col. 6.

73 Ibid.

74 Tahoe Daily Tribune, Feb. 5, 1964, p. 1, col. 6. The smaller park is expected to be approximately one-half the size originally proposed and to include five miles of sloreline. 
recreation use requirements (especially marine), transportation, housing, schools, employment, and proposed population distribution.

The chief obstacle to success of the efforts of the Regional Planning Commission is effectuation of the plan. At present there is no single agency which can be entrusted with the job of administration. It is currently intended that the plan be translated into a uniform zoning ordinance and adopted simultaneously by each of the five counties. This raises the question whether the counties together will be any more successful than they were individually. The same defects that have plagued preservation efforts in the past will not have been ehminated. Tahoe will not be under any single jurisdiction; therefore it is likely that the confusion caused by the pohitics of five separate counties will remain. Permanent residents may still be able to prevail in their argument for further development. There is no binding method of bringing independent agencies such as the California Division of Highways under the plan. Already a major proposal of the regional planners is threatened by the division of highway's potential multi-laned highway around Tahoe's west shore. ${ }^{75}$ Thus, while the Regional Planming Commission provides the brightest ray of lope to date for protection of the public interest at Tahoe, it is not a final answer.

\section{III}

\section{THE PROBLEM OF WATER ALLOCATION}

The distribution of the water that flows into and out of Lake Tahoe is an old problem that is not easily solved. There are three general areas which compete for the water: the Lake Tahoe basin, the adjoining California area, and the downstream Nevada lands. The riglits of users within those three areas are not at all certain. In addition, the United States has acquired rights for various reclaniation projects. In view of the expanding development of the basin, with the correspondingly increasing need for water and the assurance of availability of water in the future, it is mandatory that a definite allocation be made with consideration given to all interests.

\section{A. Historical Development of the Problem}

The elevation of the natural rim of Lake Tahoe at its Truckee River outlet is 6,223 feet above sea level. ${ }^{76}$ If the water level drops below this

75 See note 67 supra and accompanying text.

76 Buread of Recradsation and United States Army Corps of Engrneers, Reconnatssance Appratsal of Possible Ways to Relieve flood Damage Around latee Tamoe 1 (1957). 
elevation, outflow by gravity into the Truckee ceases. ${ }^{77}$ Downstream users of Truckee River water have traditionally claimed all of the natural overflow from Lake Tahoe. ${ }^{78}$ The water level of the lake is normally above 6,223 feet, but the level has dropped below this elevation from time to time ${ }^{79}$ severely reducing water available to the downstream users. While every effort to cut the natural rim of the lake or lower the elevation at which the lake could be tapped for gravity flow has been met by vigorous opposition from the lake's hittoral landowners and from the State of Cahifornia, ${ }^{80}$ pumping of water from the lake into the Truckee by downstream interests was permitted in particularly dry years during the 1920's and 1930's. ${ }^{81}$

The importance of controlling the lake's water level by artificial means to assure downstream users a steady water supply is readily apparent. Only the presence of a concrete dam on the Truckee 500 feet down-

7730 Ops. CAT. ATT'y Gev. 262, 263 (1957).

78 JAMES, THE LAKE OF THE SKY-LAKE TAHOE 357-58 (1915): Nature has already determined whither the overflow waters of Lake Tahoe shall go. . . [The downstream users] feel every drop of superfluous water, legally and morally, belongs to them to use as they deem proper.

79 Between 1922 and 1952, the lake level was below the rim $(6,223$ feet) at some time during each of eight years of actual record. For seven consecutive years between 1929 and 1936, the water level was below the rim. See Jonnt Cat.-Nev. Interstate Compacr Comrar's, Report of the Jomit Engtneertng Commattee, Naturat flow of the Truckee River 15 (1957).

so See 30 Ops. CaL. ATT'y Gen. 262, 265-66 (1957). As early as 1866, it was proposed by A. W. Von Schmidt, an engineer, that a tunnel from the lake be constructed through the Sierra and linked to an aqueduct intended to supply water to the San Francisco bay area. The scheme failed when San Francisco's mayor refused to sign an order authorizing a $\$ 6,-$ 000,000 bond issue to finance the enterprise. In 1903 a San Francisco attorney suggested that a tunnel be built between the lake and the Rubicon River, at an estimated cost of $\$ 500,000,000$. See HTNKLE, STERRA Nevada Lazes, 285, 292-93, 337 (1949). The hittoral owners and the State of California in 1909 blocked a plan by whicl Lake Tahoe water was to be removed through a tunnel into Washoe Lake, Nevada, under an agreement between the power company and the Reclamation Service. In 1912, the littoral owners thwarted Reclamation Service plans to lower the lake's natural rim at its Truckee River outlet. In 1930, separate suits were brought by the littoral landowners and the State of California to enjoin a contractor from digging a channel between the lake and the Truckee River. See Merrill v. LaTourrette, Eq. No. 503 (N.D. Cal. 1930); California v. Sierra Pac. Power Co., Eq. No. 508 (N.D. Cal. 1930). These actions were never tried. See 30 Ops. CAL. Atr'y Gen. 262, 265-66 (1957).

81 In 1924 a siniple contract allowed the Reclamation Service to pump 300 cubic fect per second (c.f.s.) during the irrigation season, with the proviso that nothing be done to disturb the rim of the lake. See HINRIE, STERRA NEVAda LARES 342 (1949). Under this contract, 34,000 acre-feet of water was pumped from the lake in 1924, and about the same amount in 1929. A total of 65,000 acre-feet was pumped in 1930 and 1934 under new agreements negotiated between downstream water users and Lake Tahoe littoral landowners. Althougl California participated in the arrangements for the pumping, it was not a party to the agreements. See State of Cal. Dept. of Water Resources Memorandum, Pumping From Lake Tahoe in 1930 and 1934 (1961). 
stream from the lake outlet has prevented the water level from dropping below the rim more frequently than has actually occurred. ${ }^{82}$

Under the Reclamation Act of $1902,{ }^{83}$ the Secretary of the Interior in 1903 authorized the Newlands Reclamation Project, ${ }^{84}$ in order to provide water from the Truckee and Carson Rivers for about 70,000 acres of land near Fallon, Nevada. ${ }^{85}$

As control over storage of water in Lake Tahoe was considered vital for this project, ${ }^{86}$ an agent of the Secretary posted a notice of appropriation at the damsite claiming all water flowing into Lake Tahoe, the right to hold and store the water in the lake and in the reservoir created by the dam, and the right to release and use at will up to 3,000 cubic feet per second of stored water. ${ }^{87} \mathrm{~A}$ condemnation action brought by the United States to gain control of the dam and to obtain the storage rights of the Truckee River General Electric Company resulted in a consent decree in $1915 .^{88}$ For 139,500 dollars, the United States acquired a perpetual easement in the dam, surrounding land, and controlling works, subject to an obligation to maintain the Truckee's flow at specified rates, known as the "Floriston Rates," for the benefit of the power company and its successors in interest. ${ }^{89}$ The decree also recognized the right of

82 It has been calculated that the lake's water level would have been below 6,223 feet during 16 years between 1914 and 1952 under natural conditions; this would be twice the number of years the lake was actually below the rim during the period. JorNs CAIIF,-NEv.

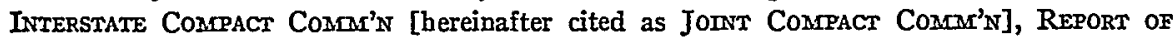

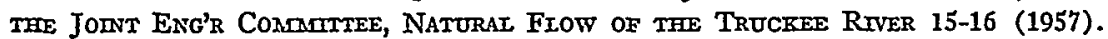

8332 Stat. 388 (1902). The Reclamation Act is often called the Newlands Act in honor of its author, Senator Francis Griffith Newlands of Nevada.

84 Originally called the Truckee-Carson Project, the name was changed to the Newlands Reclamation Project by the Secretary of the Interior in 1919. See UNITED STATES DepT. OF the Interior, BureaU of Reclamation Project, FeasibIIITIES AND AUTHORJZATIONS 659 (1957).

85 See 30 Ors. Cal. Atr'y Gen. 262, 264 (1957) ; Cal.-Ney. Interstate Comapact Coman'N of Car. [hereinafter cited as Cax. Compact Commr's], Lake Tahoe Faces Water Problems 4 (1958).

8630 Ops. Cal. Atr'y Gen. 262, 264 (1957).

87 Jonnt Cgarpact Commin, Lake Tahoe Water Problems Commetree, Prectminary List of Some of tHe More Itrportant Clams of the Untted States to Water of Lake TAFOE 1 (1958). The notice of appropriation secured the priority of the United States to 3,000 c.f.s. of water flow as of 1903. See CAL. CoMPact COMM'N, LAKE TaHOE FACEs Water Problems 2 (1958). Under California law priority in time of making an appropriation gives a superior right to all later appropriations. See HUTCHINS, IRRIGATION WATER RIGHTS IN CAITFORNIA 27-28 (1956).

88 United States v. Truckee River Gen. Elec. Co., No. 14861 (N.D. Cal. 1915). For the interesting history of events leading up to the decree, see HINKIE, SiERra Nevada LaKes $337-41$ (1949).

89 United States v. Truckee River Gen. Elec. Co., supra note 88. The decree required that the Truckee's rate of fiow at the town of Floriston, California, be maintained at 500 c.f.s. from March 1 to September 30, and at 400 c.f.s. from October I through the last day of February. 
the United States within limits to store water in and release water from Lake Talioe. ${ }^{90}$ The Reclamation Service ${ }^{91}$ operated the dam until 1926; it has since been operated by the Truckee-Carson Irrigation District under contract as the agent of the United States. ${ }^{92}$

Operation of the outlet dam to provide stored water for downstream use led to conplaints by the littoral landowners against flooding, which they attributed to the artificially high lake levels. ${ }^{93}$ Several suits were brought by the littoral landowners and the State of California prior to United States acquisition of the dam either to enjoin flooding or to require removal of the dam, but none of these claims was actually tried. ${ }^{94}$

90 The decree defines "Iow water level" by reference to a bench mark in the form of a brass bolt located on the vertical face of one of the dam walls, 3.2 feet below the top of the dam. The decree states that the bolt is 6,230 feet above sea level, although the United States Geological Survey in 1960 fixed the precise elevation at 6,228.86 feet above sea level. See Joint Compact Comm'n, Minutes of Feb. 27-28, 1961, at 30. Low water level is the lake level at which water flowing through the dam with its gates wide open equals exactly 350 c.f.s.; however, the low water level is not to be lower than five feet below the brass bolt (i.e., 6,223.86 feet elevation).

The decree first declares that whenever the power company notifles the United States in writing that it does not require 500 c.f.s. (Floriston Rates) of flow, the difference between actual flow and 500 c.is. helongs to the United States and is termed "saved waters." The decree then states that all water contained in the lake ahove a level four feet higher (i.e., 6,227.86 (eet) than low water shall be considered to belong to the United States and may be withdrawn at will. Whenever the lake level goes below $6,227.86$ feet, the United Stntes has the right to withdraw "an amount of water equivalent to that which the lake sball have contained above said four foot level at any prior time (aiter the entry of this decree, however) that the Umited States may select, together with all 'saved waters' retained in the lake since such selected time, less the amount of water that the United States shall have drawn from said lake for its own purposes since such selected time." The latter is termed "reserved water." No authoritative interpretation of this confusing provision has ever been made.

It is provided that should it become physically possible in the future for the United States to discharge 350 c.f.s. of water through the dam with its gates open when the water level is below the low water level as defined in the decree, and if the United States has established the legal right to do so, the decree may be altered to provide for a new low water point which would give the United States more waler.

Finally, the decree gives the United States a flat 36,000 acre-feet of water from the lake when the water level is low and certain conditions are met. See United States v. Truckee River Gen. Elec. Co., No. 14861 (N.D. Cal. 1915). An acre-foot is the quantity of water which will cover an area of one acre to a depth of one foot.

While the rights thus given under the decree are considerable, it is apparent that ownership by the United States of all water flowing into the lake was not recognized despite the 1903 notice of appropriation, nor was the Umited States given an unrestricted right to release and use stored water.

91 Predecessor of the present Bureau of Reclamation.

9230 OrS. CAI. ATT'y GEN. 262, 264 (1957). The Truckee-Carson Irrigation District was organized in the early 1920's by water users under the Newlands Project to coordinate repayment of project construction costs and to assume control and maintenance of the project. Ibid.

98 Ibid.

94 See Westeru Co. v. Truckee River Gen. Elec. Co., No. 15.610 (N.D. Cal. 1912); 
After the United States acquired control of the dam, unusually high lake levels were encountered during the period 1915 through $1917 . .^{95}$ In response to vigorous complaints by the littoral landowners and the State of Cahifornia, the Secretary of the Interior held a hearing in 1919. The Secretary promised to request the United States Attorney General to institute legal actions to determine the authority of the United States to operate the dam and to condemn whatever private rights were taken as a result of its operation. ${ }^{96}$ No action was ever brought by the Attorney General.

The severe water shortages in the 1920's and early 1930's emphasized the need for additional water storage in the Truckee River watershed to provide for downstream irrigation and power interests. The Bureau of Reclamation proposed construction of a dam and reservoir on a tributary of the Truckee River to meet this need. To secure the approval of competing claimants to Lake Tahoe water, the Truckee River Agreement was negotiated in $1935^{97}$ between the United States, the Truckee-Carson Irrigation District, the Washoe County (Nevada) Water Conservation District, the Sierra Pacific Power Company (successor in interest to the Truckee River General Electric Company), and a number of individual downstream Nevada users. ${ }^{98}$ The agreement included provisions which (1) required construction of Boca Reservoir with a storage capacity of 40,000 acre-feet; (2) confirmed and incorporated by reference the contents of the 1915 decree in United States v. Truckee River General Electric Company,99 including specific reaffirmation of the Floriston Rates, (3) prescribed "Reduced Floriston Rates" for winter withdrawals from Lake Tahoe under certain low water conditions, ${ }^{100}$ and (4) fixed the operating levels of the lake. ${ }^{101}$ The provisions specifying lake levels,

California v. Truckee River Gen. Elec. Co., Eq. No. 304 (N.D. Cal. 1912), both dismissed in 1939 without prejudice; Western Co. v. Murray F. Vandall, No. 3760 (Sup. Ct. of Placer County 1907), dismissed in 1908 at the stipulation of the parties.

95 The lake level reached 6,229.7 feet above sea level in 1916 and 1917. 30 Ops. Cax. ATT'Y GEN. 262, 265 (1957).

98 The Director of the Reclamation Service admitted at the learing that littoral owners lad been damaged by unnaturally high water levels produced in part by the dam. He pointed out that the Reclamation Service had offered to compensate those damaged littoral owners who would in return give their permission to the United States to vary the natural level of the lake, but few accepted. Ibid.

97 Althougli the agreement is dated 1935, it was not finally executed until 1937. Id. at 266.

98 See Truckee River Agreement (1935).

99 No. 14861 (N.D. Cal. 1915); see text accompanying notes $88-90$ supra.

100 The reduced rate schedule, which is to be effective from November 1 to March 31 of each winter season, requires the release of 350 c.f.s. of flow whenever the lake level is between $6,225.25$ and $6,226.0$ feet, and 300 c.f.s. of flow whenever the lake level falls below 6,225.25 feet. See Truckee River Agreement art. I(K) (1935).

101 The Truckee-Carson Irrigation District, as agent of the United States in charge of 
which in effect fixed the low level of the lake at an elevation of 6,223 feet and the maximum high water level at 6,229.1 feet were included at the insistence of the State of Califorma and the littoral landowners. ${ }^{102}$ As a result, the Truckee River Agreement reflected the acquiescence of the State of Cahformi ${ }^{103}$ and the Lake Tahoe landowners, ${ }^{104}$ although neither was a party to the agreement.

The next legal development with respect to water allocation occurred in 1944 when the final decree was issued in the case of United States v. Orr Water Ditch Company. ${ }^{105}$ This decree, commonly referred to as the Truckee River Final Decree, adjudicated the water rights of all users of the Truckee River except the Lake Tahoe littoral landowners and the riparian owners on the river in California. ${ }^{106}$ The decree provides that (1) the Umited States lias the right to loold and store all water entering Lake

the dam operation, is required to prevent, insofar as practicable, lake water levels in excess of 6,228.0 feet. Snow survey data are used to predict water levels in the lake and provide a basis for release of an appropriate amount of water into the Truckee. Id. art. III(F) (1935). Discharge is required whenever the actual lake level is above 6,228 feet. Normally the U.S. is not entitled to releases in excess of the amounts fixed in the 1915 decree (see note 89 supra). However, in order to prevent overflow and high water damage, the United States and the power company are required to petition the court for a temporary order allowing such releases. Id. art. III(F) (4).

The agreement forbids lowering the minimum lake level below the elevation of the natural rim except under narrowly prescribed conditions. The natural conditions in the bed and banks of the lake and the Truckee River between the outlet and the dam are not to he altered or disturbed without the approval of the Cahifornia attorney general. In addition, no party is to create or cause the creation of additional outlets from the lake. Finally, no water is to be removed from the lake by any means other than gravity flow, unless either the Secretary of the Interior declares it necessary for samitary or domestic uses or the Health Departments of Califorma and Nevada file a certificate with the respective state attorncys general specifying the necessity of the removal for sanitary or domestic uses. Id. art. $\mathrm{XXV}(\mathrm{G})$.

10230 Ops. Cal. Atr'y Gen. 262, 266 (1957).

103 The attorney general of Cahiornia expressed his approval in a letter to the United States Secretary of the Interior in 1934, although he specifically withheld assent to the continuing recognition given by the agreement to the 1915 consent decree between the Umited States and the Truckee River General Electric Company, which Cahforma had traditionally opposed. Id. at 267 .

104 The Governors of Cahforma and Nevada appointed a committee which served in an advisory capacity to the parties to the agreement. In a poll conducted by the committee, $61 \%$ of the Cahfornia littoral owners expressed approval of the proposed agreement. See Lake Tahoe Interstate Water Conference Commttee, Premtminary Report 1 (1952). A majority of the California representatives on the committee also approved the agreement. 30 Ops. CAL. Atr'y Gen. 262, 266 (1957).

$105 \mathrm{Eq}$. No. A3 (D. Nev. 1944). The action was commenced many years earher, and a temporary restraining order defining appropriative water rights and estabhisbing a priority date for each right had been issued in 1926. See Compremensive STudy 38.

10630 Ors. CaI. ATr'y Gen. 262, 267 (1957). Several hundred downstream users were parties-defendant in the action. The decree defined the right of cach user to appropriate specific amounts of water from the Truckee River. 
Tahoe up to 3,000 cubic feet per second (c.f.s.) of flow and to the extent of the dam's capacity, ${ }^{107}$ with rights dating from $1903,{ }^{108}$ and to release water at will from the water stored by the dam; (2) the 1915 decree in United States v. Truckee River General Electric Company is "recognized and confirmed," and the Truckee River Agreement is incorporated by reference; ${ }^{109}$ (3) Truckee River water, including stored water released from Lake Tahoe by the United States, may be used for irrigation of 232,800 acres of land of the Newlands Project, ${ }^{110}$ for storage in Lahontan Reservoir, ${ }^{111}$ for generating power, and for domestic water supply of cities and towns within the project; and (4) the United States may divert water from the Truckee River with rights dating from 1859 to irrigate 5,875 acres of land belonging to the Pyramid Lake Indians, not to exceed 30,086 acre-feet annually. ${ }^{112}$ Some of these provisions are irreconcilable,

107 The basis of the allocation is that the spillway is six feet above the floor of the dam. The right to 3,000 c.f.s. of flow is equal to 5,949 acre-feet per day, or $2,171,385$ acrefeet per year.

108 The priority is based upon the notice of appropriation posted at the dam by an agent of the United States Secretary of the Interior in 1903. See text accompanying note 87 supra.

109 Thus, while the decree itself does not provide for any limitations on lake water levels, the incorporation by reference of the Truckee River Agreement adopts the water level restrictions imposed by that agreement.

The Truckee River Final Decree and the 1915 Decree present significant differences in the water rights recognized as belonging to the United States. The Final Decree, while purporting to reaffirm the 1915 Decree, gives the United States all water entering the lake and the Truckee up to 3,000 c.f.s. of flow measured at the lake's outlet. This amount of flow is equivalent to over 2 million acre-feet of water per year. Since the Truckee River Agreement, incorporated in the Final Decree by reference, fixed the operating levels of the lake between 6,223 and 6,229 feet, only six feet of storage space above the natural rim is available. Lake Tahoe occupies about 120,000 acres; therefore, only about 720,000 acre-feet of storage exists in the top six feet-far less than the amount of water necessary to produce 3,000 c.f.s. of flow continuously for one year. Thus, the Final Decree apparently gives all water entering into or flowing from the lake to the United States. The 1915 Decree is much less generous. See note 90 supra.

The Final Decree states that the United States is entitled to store, discharge, and control water in the lake as provided in the 1915 Decree "in addition" to the right to ownership and storage of all water entering the lake up to 3,000 c.f.s. However, the United States unay discharge water from the lake "subject to" the 1915 Decree in order to deliver 1,500 c.f.s. (about 1,085,000 acre-feet annually) of flow, after transportation loss, at a point on the Truckee River below Sparks, Nevada. Finally, the 1944 Decree provides that the United States is entitled to release at will any water stored in Lake Tahoe.

110 The water diverted from the Truckee River for irrigation cannot exceed 3.5 acre feet per acre for botton lands or 4.5 acre-feet per acre for bench lands, computed without regard to transportation loss. Botton lands are those lying along the river, while bench lands refer to tracts above the strcam bed along valley slopes.

111 Lahontan Reservoir, located about fifteen miles west of Fallon, Nevada, is used to store water from the Truckee and Carson Rivers for use in the Newlands Reclamation Project. See appendix.

112 Although identical provisions are included in the Truckee River Agreement of 1935, 
and it is difficult to determine precisely what rights of the United States were recognized. ${ }^{113}$ The decree also provided for the appointment of a water master by the court to carry out and enforce. the provisions. ${ }^{114}$

\section{B. The Problem Today}

The total water content of Lake Tahoe is estimated to be 122 million acre-feet, enough to inundate the entire State of Cahifornia to a depth exceeding fourteen inches. ${ }^{115}$ Yet, it has frequently been said that the area is "water deficient" when considered with respect to the present and future needs of the Tahoe basin. ${ }^{110}$ Since the Truckee River Agreement of 1935 permits storage of water for downstream use only in the 6.1 feet between elevations 6,223 and $6,229.1,{ }^{117}$ only about 720,000 acre-feet can be stored for use. ${ }^{118}$ Since more than one million acre-feet of water could conceivably be used for irrigation of the Newlands Project alone, ${ }^{110}$ all of the water of Lake Tahoe above 6,223 feet could be taken for downstream use under the Truckee River Final Decree. This situation has prompted the statement that "the lake is now operated almost exclusively for the benefit of the downstream power, irrigation and domestic users."120

which the court incorporated by reference into its decree, they are reproduced in the decree in their entirety.

The decree limits the diversion for the benefit of the Pyramid Lake Indians to a maximum fiow of 127 c.f.s., not to exceed 30,086 acre-feet per year. Since 127 c.f.s. of flow for one year would produce about 90,000 acre-feet of water, the only apparent significance of the alternative figures is to allow greater diversions in the dry months of the year-i.e., 127 c.f.s. may be diverted in dry months, but since to continue diversions at this rate would exceed the overall annual acre-foot limitation, the rate of flow in other months must be less than one-third of 127 c.f.s. to compensate.

By 1956 the Pyramid Lake Indians were using only about half of the amount of the water available to them under the decree. Stinson, Sonie Legal Princirles Bearno on Federal Interests in the Proposed Nevada-Calfformia Compact 4 (1956).

113 See note 109 supra.

114 Expenses and compensation of the Water Master, determined periodically by the court, are borne in thirds by the United States, the Sierra Pacific Power Company, and the remaining users whose rights were adjudicated in the action. The office of the Water Master is presently located in Reno, Nevada.

115 Lake Tamoe area Councin, Geographic Factors Rexative to the Lake tamoe BASIN 6 (1960).

116 See Compremensive Study 38; Cal. Compact Comm'n, Lake Tahoe Faces Water Problems 4 (1958); Tahoe Daily Tribune, Aug. 12, 1963, p. 1, col. 6 and March 5, 1964, p. 1 , col. 1 .

117 See notes 101-02 supra and accompanying text.

118 Cat. Compact Comm'n, Lake Tamoe Faces Water Problears 4 (1958).

119 Since 3.5 to 4.5 acre-feet of water for each of 232,800 acres of land can be diverted from the Truckee River for use in the Newlands Project under the Truckee River Final Decree (see note 110 supra and accompanying text), total diversions could exceed 1,000,000 acre-feet annually even without the addition of amounts of other diversions for power, irrigation, and domestic use.

120 CaI. Compact Common, Lake Tafoe faces Water Problems 4 (1958). 
Should all water above 6,223 feet be diverted for downstream use, littoral landowners, who suffer most from abnormally low water levels, ${ }^{121}$ would have no choice but to deplete the lake level below its natural rim to meet their own basic water requirements. This step would be necessary because the Umited States was given prior rights to water and storage in Lake Tahoe by the 1915 consent decree, the 1935 Truckee River Agreement, and the Truckee River Final Decree, although the littoral landowners were not parties to any of these actions, and therefore not bound by them. ${ }^{122}$

Use of water from Lake Tahoe and the Truckee River for irrigation and development of downstream areas lying almost entirely in Nevada is continued in the Washoe Reclamation Project. ${ }^{123} \mathrm{~A}$ new reservoir, ${ }^{124}$ which is intended chiefly to provide irrigation for nearly 50,000 acres in Nevada as well as backup storage for the Newlands Project, is to be constructed on the Little Truckee River. Operation of this reservoir will affect the Lake Tahoe water levels. ${ }^{125}$ While certain safeguards for Cahifornia's interests were included in the authorizing act upon recommendation of Cahifornia state agencies, ${ }^{126}$ the project lias nevertheless

${ }^{121}$ See $i d$. at 3. Aside from aesthetically distasteful effects, such as exposed rocky and weedy beaches, the most objectionable conditions associated with low water levels include exposure of water intake ducts, wharves and piers, and interference with boating and swimming. See Field Research Company, Property OWners in the Lake Tahoe Basin Appratse Proposed Water Lever Plans for the Lake A-13 (1958); Cal. Compact Comm'n, Committee on Pumping from Lake Tahoe, Minutes for Aug. 23, 1961, at 6 .

122 The California attorney general has expressed the opinion that the Lake Tahoe hittoral landowners, although not bound by the Truckee River Final Decree, have apparently been barred by the statute of limitations and laches and, therefore, have no present cause of action against those who are regulating lake water levels for water storage, generation of hydroelectric power, and consumptive use downstream on the Truckee. 30 Ops. CAL. ATr'y GeN. $262,263,269-72$ (1957). The opinion concludes that the littoral landowners would probably have a cause of action for damages if changes were inade either in the present methods of operating the dam or in the himits of the lake levels. Id. at 262, 272-74.

12370 Stat. 775 (1956).

124 Stampede Reservoir is to have a capacity of 175,000 acre-feet under the requirements of the authorizing act. The project also calls for construction of Watasheamu Reservoir on the Carson River.

125 The operating schedule proposed by the Bureau of Reclamation for stored waters of the lake under the Washoe Project calls for higher lake levels for longer periods of time than have existed thus far under actual conditions. See CaL. Compract Conos'n, LaIE TAEOE Faces Water Problexs 3 (1958). The Bureau of Reclamation has recognized that modification of the Truckee River Agreement of 1935 and the Truckee River Final Decree of 1944 is necessary for the alteration of water rights and for exchanges of water among various reservoirs contemplated by the Washoe Project. See Joint Compact Comm'n, Minutes of Dec. 21, 1956, attachment B. However, modification would not necessarily involve consent of the hittoral landowners, who were not parties to the agreement and decree.

126 California state agencies recommended that (1) the new regulatory storage and water supply for the project be based upon runoff of streams as reduced by the present and future use in the areas of origin in California; (2) the amount of water available to the project 
been criticized by the California Director of Water Resources. ${ }^{127}$

The future promises aggravation rather than relief of the water problem. While the present demand for water within the Lake Tahoe basin is only 5,300 acre-feet, gross municipal and domestic requirements

be completely determined and defined through an interstate compact between California and Nevada; (3) Stampede Reservoir be so constructed that it could be enlarged to care for future water requirements of lands in Califorma; (4) a dependable water supply be provided to lands in the Carson Valley in California, as well as those in the same valley in Nevada; (5) Lake Tahoe storage be controlled to solve the problems of lake shore property damage; (6) adequate operation provisions be included to maintain fish and wildlife and protect migrating deer. See letter from Assistant Director, Bureau of the Budget, to the Secretary of the Interior dated May 20, 1955, reprinted in United States Departarent of the Intertor, Bureau of Reclamation, Project Feasibitities and Authorizations 96366 (1957). Most of these recommendations were incorporated into the authorizing act, including provision for a greater capacity of Stampede Reservoir by 49,000 acre-feet, and a reservation permitting appropriation of project water intended solely for generation of hydroelectric power in Califorma. The reservation shall not apply if an interstate compact covering the distribution of waters of the Truckee River is negotiated by Cahifornia and Nevada, since the project must then conform to the compact provisions.

Since Section 8 of the Reclamation Act of 1902 requires the Secretary of the Interior to proceed in conformity with state law in appropriation, distribution, and use of watcr for irrigation (but see notes 132, 138-39 infra), California was able to provide for additional safeguards of its interests. To appropriate water in California since 1914, the exclusive procedure, detailed in CAL. WATER CODE $\$ \S 1200-1677$, must be followed. An application for a permit to appropriate must be filed with the State Water Rights Board. In granting permits to the Bureau of Reclamation to appropriate unappropriated water of the Little Truckee River for the Washoe Project, the board reserved the right for California users to appropriate up to 30,000 acre-feet per year of the unappropriated waters in the Truckee River system determined as of the date of the issuance of the permit, but limited to 30/156ths of the unappropriated water at Stampede Reservoir annually. The board also specified that Stampede cannot be operated to the detriment of existing water uses in California and required that certain releases be maintained below the reservoir to protect fish life in the river. Finally, the board retained jurisdiction to amend the permits to conform to the CaliforniaNevada Interstate Compact now under negotiation. See State of CalfForrsa, ThIRd Annuar Report of the State Water RTohts Board 9-10 (1959); JonNt COMPaCT Coman's, Backgrodnd Inforasation on the CaI.-Nev. Interstate Cosapact Negotiatigns 7 (1961). For discussion of the compact negotiations, see text accompanying notes 147-97 infra.

${ }^{127}$ Letter from William E. Warne, Director of the Department of Water Resources of California, to Hugh P. Dugan, Regional Director, Region II, United States Dept. of the Interior, Bureau of Reclamation, Dec. 11, 1962. While he recognized that Stampede Reservoir will be sufficient to satisfy the inumicipal water requirements of both Cahifornia and Nevada until the year 2005, with possibilities of enlargement at a later date, Mr. Warne voiced the following objections to the Washoe Project: (1) municipal water service and recreation are not specifically included as project purposes; (2) while provision was made in the authorizing act for offer of project water under contracts to users in Alpine County, Cahifornia, for irrigation, this offer is made contingent upon the availability of project water for development of "new land" in Nevada. Thus, there is no absolute commitment of water for use in Cahfornia, nor have Califorma interests yet been offered a proposed contract for water service under the project; (3) Nevada users could gain an increase in equitable rights to water under the project in the absence of proper safeguards for California, thereby prejudicing California should the interstate compact negotiations fail and a suit in the United States Supreme Court become necessary. Ibid. 
are expected eventually to reach about 40,000 acre-feet. ${ }^{128}$ To preserve lake levels within safe limits and to prevent unfavorable reaction from downstream users, additional storage for water must be found in the basin. Storage in the lake itself for littoral interests is not practical. Since all storage between 6,223 and 6,229.1 feet has been appropriated by the United States for use by downstream interests, additional water from the lake can be developed only by allowing storage above 6,229.1 feet or drawing water from below 6,223 feet. Use of space above the present capacity would produce higher lake levels than the maximum 6,229.1 feet with consequent flooding of littoral land. ${ }^{129}$ Use of space below the present limits of storage would result in lake levels below 6,223 feet in dry years, with concomitant pressure by downstream users for lowering the lake's natural outlet, for pumping, or for construction of an outlet tunnel. Since storage elsewhere in the basin is not practical for littoral owners, the most feasible alternative to storage in the lake is construction of substitute storage elsewhere for the downstream Nevada interests now dependent on water from Lake Tahoe. Construction of new reservoirs, however, apparently has not been aimed at relieving the downstream demand for presently stored Lake Tahoe water, but has been directed toward providing irrigation and power for new land in Nevada.

It might be noted that lake residents simply use water, without concern whether it came from above or below 6,223 feet. Since the United States claims all storage above that figure, it could be maintained that the littoral owners must only use water below the natural rim of the lake. Acute controversy appears likely only during dry cycles, such as that of 1923-34, whicl are expected to occur on an average of once every fifty years. ${ }^{130}$ When the lake level dips below 6,223 feet, water to the downstream users is cut off. The United States, on its own behalf and for the downstream users, could argue that littoral owners were taking water from its storage space prior to the drop below the natural rim, and that an equivalent amount of water from below that level is due them as compensation. The littoral owners could argue in reply that even if the

128 Compremensive Study 35-36; Cad. Comipact Compm'n, Lake Tamoe Faces Water Problears 5 (1958).

120 Studies by the Corps of Engineers, United States Army, indicate that direct damage to shoreline and docking facilities begins at $6,227.5$ feet. High water periods greatly reduce usable beach areas, while storm-driven waves cause shoreline erosion and damage to piers, docks, and other shoreline installations. Damage exceeding $\$ 200,000$ was estimated by the Corps in 1951 when water level reached 6,228.9 feet. Cat. Compact Comm'N, Laze Tamoe Faces Water Problemss 2-3 (1958).

130 See Bureat of Reclasmation and United States Army Corps of Engineers, Reconnatssance Appratsal of Possible Ways to Relieve flood Dameage Around Late TAHOE 4 (1957). 
United States appropriation of 1903 were valid, ${ }^{131}$ the downstream users are entitled only to an equitable share of the natural overflow from the lake. ${ }^{132}$ The difficulty of assessing these possible contentions is lheiglitened

131 The littoral owners lave never challenged the procedural validity of the appropriation and thus the validity under California law has never been conclusively established in a court decree binding on all parties. Still, the likelihood of a successful attack is questionable. The United States in 1903 followed the procedure for appropriation required by California at that time, which required only that a notice be posted at the proposed point of diversion, a copy filed with the county recorder, construction be started within prescribed periods, and the water be applied to beneficial use. See Hutchmos, Irrigation Water Righis In CatrFORNIA 25 (1956). It is not important that the United States did not immediately put the total claimed appropriation (3,000 c.f.s.) to beneficial use since an irrigation project may be developed gradually in progressive units. The length of time allowed for completing the appropriation depends upon the circumstances. Id. at 26. The original plan must include the entire area of the project in one appropriation, and construction of works and application of the water to beneficial use must be carried out with reasonable diligence. Ibid. Depending on the timing and amount of water put to beneficial use by the United States, the littoral landowners could possibly attack the claimed diversion right as being unreasonable and in excess of the requirements of the United States at the time made. See id. at 28. Since 3,000 c.f.s. is equivalent to over 2 million acre-feet of water per year, see note 109 stlpra, far more than the lake's natural fiow has ever produced, the original appropriation was obviously excessive and included an amount of water never put to beneficial use. The littoral owners could argue that appropriation of water is allowed oniy for water not already appropriated and that the United States' appropriation, amounting to all the natural flow from the lake, violated prior appropriative rights. The extent of prior appropriation by basin landowners, however, is unknown and has never been adjudicated. In addition, riparian rights attach to land bordering a lake. Turner v. James Canal Co, 155 Cal. 82, 99 Pac. 520 (1909). Riparian rights are superior to subsequently asserted appropriative rights in California. United States v. Fallbrook Pub. Util. Dist., 165 F. Supp. 806 (S.D. Cal. 1958); Thorne v. McKinley Bros., 5 Cal. 2d 704, 56 P.2d 204 (1936); Gallatin v. Corning Irrigation Co., 163 Cal. 405, 126 Pac. 864 (1912); cf. Haight v. Costanich, 184 Cal. 426, 194 Pac. 26 (1920); Sherwood v. Wood, 38 Cal. App. 745, 177 Pac. 491 (1918). Riparian rights are not lost by disuse, but exist regardless of whether they are exercised. Hargrave v. Cook, 108 Cal. 72, 41 Pac. 18 (1895); Porters Bar Dredging Co. v. Beaudry, 15 Cal. App. 751, 115 Pac. 951 (1911). Thus, the littoral owners might assert superior riparian rights to a portion of the lake's natural overflow.

132 The United States appropriation of 1903 was intended to provide water for future development and irrigation projects in Nevada. In claiming all the water fiowing into the lake, the then existing and future needs of littoral landowners were ignored. The United States approach overlooks the doctrine of equitable apportionment followed by the United States Supreme Court (see notes 135-37 infra and accompanying text), under which California and Nevada would be given fair shares of water based on all cquitable principles. Thus, in Nebraska v. Wyoming, 325 U.S. 589 (1945), a suit for equitable apportionment between the two states, the Secretary of the Interior had appropriated water in Wyoming for use in that state, and pursuant to section 8 of the Reclamation Act (see note 139 inffra) had followed the appropriation procedure established by Wyoming law. It was held that the water appropriated was not the property of the United States but was appurtenant to the reclaimed land, and the owner of that land owned the water. It was further held that the United States was not entitled to a separate allocation of water, since the water rights appropriated by the Secretary were in the individual landowners, and Wyoming was permitted to represent parens patriae both the United States as an appropriator and the individual landowners in the suit for equitable apportionment. The court stated in dictum 
by the unreality of regarding the lake as stratified into distinct levels, each belonging to different parties, rather than considering it as a continuum where withdrawals by one affect all users.

\section{An Attempt to Meet the Problem: The California-Nevada Interstate Compact}

As neither the littoral landowners nor the states of California and Nevada have been parties to the court decrees and agreement recognizing the interests of the downstreanı users, their rights to water fron the lake and the Truckee River have never been conclusively determined. One of the principal ways of apportioning water in interstate streams is through an original suit in the Suprenie Court of the United States between the states involved..$^{183}$ The decree entered in such a suit is binding not only on the litigant states but on the individual citizens of those states as well..$^{134}$

The Supreme Court has rejected the absolute right of one state to retain the waters of an interstate strean within its borders in favor of the doctrine of equitable apportionment. ${ }^{135}$ In applying this doctrine, the

that it would not be proper to analogize the facts of the case with a situation where "the United States acquires property within a State and asserts its title against the State as well as others." 325 U.S. at 629. See also Ickes v. Fox, 300 U.S. 82 (1937); Hudspeth County Conservation \& Reclamation Dist. No. 1 v. Robbins, 213 F.2d 425 (5th Cir.), cert. detied, 348 U.S. 833 (1954). A recent case in a federal district court followed these cases in holding that the mere impounding and diversion of water by the United States under the reclamation laws did not vest ownership of the water or the water rights in the United States; it is not clear whether the United States Supreme Court's reversal in the case was meant imphedly to overrule Nebraska v. Wyoming and Ickes v. Fox, supra. See Rank v. Krug, 142 F. Supp. 1, 99 (S.D. Cal. 1956), aff'd in part and rev'd in part, 293 F.2d 340, 354-55 (9th Cir. 1961), modified, 307 F.2d 96 (1962), affd in part and rev'd in part sub nom. Dugan v. Rank, 372 U.S. 609 (1963).

Whereas in the present case the Secretary of the Interior appropriated water in California for use in Nevada and would apparently assert rights to the water adverse to those of Califorma, it is difficult to believe that the Court would sanction an appropriation of all the lake's natural flow for development of Nevada projects, while freezing California to uses existing in 1903. It would appear more likely that in a suit between Califorma and Nevada, water appropriated by the United States would be charged to the share equitably apportioned to Nevada, on the theory that the Nevada users are the actual owners of the water.

133 Hutchins, Selected Problems in the Law of Water Rights In the West 411 (1942); King, Interstate Water Compacts, in WATER Resources AND tHe LAW 355, 377-85 (1958); Stinson, Interstate Water Compacts, 45 CaIIF. L. REv. 655, 656 (1957). The jurisdiction of the Supreme Court over such disputes is derived from the U.S. CoNST. art. III § 2 .

134 See Dyer v. Sims, 341 U.S. 22 (1951); Hinderlider v. La Plata Co., 304 U.S. 92 (1938); Kentucky v. Indiana, 281 U.S. 163 (1930); Kansas v. Colorado, 206 U.S. 46 (1907).

135 See Kansas v. Colorado, 206 U.S. 46 (1907); Kansas v. Colorado, 185 U.S. 125 (1902). 
Court has stated that while priority of appropriation is the guiding principle, ${ }^{136}$ other relevant factors are to be considered. ${ }^{137}$

Since the Court has also stated in dictum that the right of the Secretary of the Interior, when claiming an appropriation of water for federal irrigation projects under the Reclamation Act of 1902, can be no greater than the right of the state in which the appropriation was made, ${ }^{138}$ the claims of the United States to Lake Tahoe water could be adversely affected by interstate hitigation. Recent decisions of the Supreme Court cast doubt on this dictum. ${ }^{139}$ It is questionable, nevertheless, whether the

136 It is questionable whether the doctrine of prior appropriation would be applied in a suit between California and Nevada, since the latter state bas repudiated the doctrine of riparian rights. See Jones v. Adams, 19 Nev. 78, 6 Pac. 442 (1885); Hutchuns, The NevadA LAW OF WATER RIGETS 6-8 (1955). California recognizes both appropriative and riparian rights. The Supreme Court indicated the prior appropriation doctrine would only be applied in interstate apportionment cases where both states recognized that doctrine as the sole rule of priority. See Wyoming v. Colorado, 259 U.S. 419, 470-71 (1922).

137 Such factors include plysical and chmatic conditions, the consumptive use of water in the several sections of the river, the character and rate of return flows, the extent of established uses, the availability of storage water, the practical effect of wasteful uses on downstream areas, and the damage to upstream areas compared to the benefits to downstream areas if a limitation is imposed on the former. Nebraska v. Wyoming, 325 U.S. 589, 618 (1945).

138 See Nebraska v. Wyoming, 295 U.S. 40, 43 (1935): "The bill alleges, and we know as a matter of law, that the Secretary and his agents, acting by authority of the Reclamation Act and supplementary legislation, must obtain permits and priorities for the use of water from the State of Wyoming in the same manner as a private appropriator or an irrigation district formed under state law. His rights can rise no higher than those of Wyoming, and an adjudication of the defendant's rights will necessarily bind bim."

139 Controversy in recent cases has centered around $\S 8$ of the Reclamation Act of 1902, which provides: "That nothing in this Act shall be construcd as affecting or intended to affect or to in any way interfere with the laws of any State or Territory relating to the control, appropriation, use, or distribution of water used in irrigation, or any vested rigltt acquired thereunder, and the Secretary of the Interior, in carrying out the provisions of this Act shall proceed in conformity with such laws, and nothing herein shall im any way affect any right of any state or of the Federal Government or of any landowner, appropriator, or user of water in, to, or from any interstate stream or of waters thereof; Provided, That the right to the use of water acquired under the provisions of this Act shall be appurtenant to the land irrigated, and beneficial use shall be the basis, the measure, and the limit of the right." 32 Stat. 388 (1902), 43 U.S.C. $\S 383$ (1946). The customary practice of the Bureau of Reclamation in acquiring water rights is to file a notice of appropriation pursuant to state Jaw. See United States v. Gerlach Live Stock Co., 339 U.S. 725, 758 (1950) (concurring and dissenting opinion). In Ivanhoe Irrigation Dist. v. All Parties, 47 Cal. 2d 597, 306 P.2d 824 (1957), the California Supreme Court held that $\S 5$ of the Reclamation Act, providing that no water produced by a reclamation project shall be sold for lands in excess of 160 acres in single ownership, conflicted with state law and was therefore invalid under $\$ 8$ of the Reclanuation Act. The United States Supreme Court reversed, stating: "As we read \& 8, it merely requires the United States to comply with state law when, in the construction and operation of a reclamation project, it becomes necessary for it to acquire water rights or vested interests therein. But the acquisition of water rights must not be confused with the operation of federal projects. ... We read nothing in $\S 8$ that compels the Umited States to deliver water on conditions imposed by the State. ... Without passing generally on the coverage 
Supreme Court would equitably apportion water to California, only to have the largest part of it used in Nevada under the claimed appropriation. ${ }^{140}$

of $\S 8$ in the delicate area of federal-state relations in the irrigation field, we do not believe that the Congress intended $\S 8$ to override the repeatedly reaffirmed national policy of $\S 5$." Ivanhoe Irrigation Dist. v. McCracken, 357 U.S. 275, 291-92 (1958). The Court pointed out that rights necessary to carry on a project could be acquired by the United States either by condenunation or by responding in damages to the owners if the rights were seized without condemnation. Id. at 291. In City of Fresno v. State of California, 372 U.S. 627 (1963), the Court held that $\$ 8$ did not require the Bureau of Reclamation to comply with California statutes relating to preferential rights of counties and watersheds of origin and to the priority of domestic over irrigation uses. The Court stated that $\$ 8$ does not prevent the United States from exercising the power of eminent domain to acquire any water rights necessary for a project, the only function of state law being to define the property interests, if any, for which compensation must be made. In Dugan v. Rank, 372 U.S. 609 (1963), the Court reaffirmed the Ivanhoe decision, supra, holding that water riglts may be physically seized by "inverse condemnation," with the owners entitled to bring a court action for conpensation.

These recent cases leave open the meaning of $\S 8$ of the Reclamation Act and seem to undercut the dictum in Nebraska v. Wyoming, 295 U.S. 40 (1935), stating that the rights of the Secretary of the Interior when appropriating water under state law are limited by the right of that state in interstate suits for equitable apportionment. The cases, however, may be reconciled. It is clear that water rights may be acquired by the United States for reclamation projects either by appropriation made under state law, by condenmation, by grant, or by inverse condenination. If the United States proceeds by way of condeinnation or inverse condemnation, compensation is due to the owner of the rights taken. However, no compensation need be paid to the state for a valid appropriation, if the United States chooses to proceed by that method. While the only function of state law where rights are taken by condemnation or inverse condemnation for a reclamation project is to define the interest taken, it could be maintained that state law applies in its entirety when the United States elects to appropriate water. Thus, the United States must present an application to the State Water Rights Board in Cahifornia in order to appropriate water, and nuust meet the statutory requirements for a valid appropriation. In order to obtain the advantage of acquiring water without having to pay for it, the United States is bound by state law applicable to water appropriation. The appropriation is therefore a creature of and controlled by state law. This interpretation would establish the continuing validity of the Nebraska v. Wyoming dictum, consonant with the more recent Ivanhoe, Dugan, and City of Fresno cases, supra. If this interpretation is applied to the Lake Tahoe situation, where the United States chose to proceed by appropriation, the validity of the appropriation will be determined by state law. In addition, since Califorma recognizes riparian rights, the appropriation is subject to that doctrine as well as the doctrine of prior appropriation (see note $136 \mathrm{supra}$ ). Finally, the appropriation of the United States would be limited in a suit between Nevada and Califorma for equitable apportionment by the amount of water apportioned to Nevada, under the holdings of Ickes v. Fox, 300 U.S. 82 (1937) and Nebraska v. Wyoming, 325 U.S. 589 (1945) (see note 132 supra). If the United States wishes to seize lake water rather than stand on its appropriation, then compensation would be due for any rights taken or infringed upon. The alternative to the suggested approach is the view that the United States as an appropriator of water is not subject to state law and is not affected by the doctrine of equitable apportionment. The Bureau of Reclamation could then with impunity appropriate water from an interstate strcam in one state for use in another without having to pay for it, without being bound by state law, and without being subject to the equitable apportionment doctrine intended to maintain a fair balance in water allocation between contending states.

140 See note 132 supra. If the Court allocated 200,000 acre-feet of a total 700,000 acre- 
Although suit between Califorma and Nevada appears imminent if apportionment by negotiation fails, ${ }^{141}$ there are cogent reasons why states are reluctant to resort to such drastic measures, not the least of which are the expense and time involved, and the general insufficiency of result. ${ }^{142}$

An alternative to an original suit before the Supreme Court is negotiation of a compact between the states involved, a procedure specifically recognized by the federal Constitution. ${ }^{143}$ The compact approach, which has been recommended by the Supreme Court ${ }^{144}$ as well as praised by a number of knowledgeable writers, ${ }^{145}$ has been adopted for a wide variety of subjects of interstate concern, including boundaries, water apportionment, samitation, area development, ports, and parks and recreation. ${ }^{140}$ The California and Nevada legislatures established an interstate compact

feet to California, and the United States were allowed to claim the 200,000 acre-feet for use in Nevada under its appropriation in California, equitable apportionment by the Court would be meaningless. California would receive no water even though suit were instituted. Since the United States appropriation was made for beneficial use in Nevada, it seems likcly that the United States' claim would be included as part of the Nevada allocation, thereby insuring that the California allocation would accrue to the benefit of California users.

141 Regarding the Walker River, a Sierra streanı which is also subject to the interstate compact negotiations between Nevada and Cahifornia, the Cahifornia legislature passed a resolution in 1961 directing the attorney general to institute suit in the United States Supreme Court against Nevada for equitable apportionment of water when such an action becomes necessary in his judgment. See Joint Compact Comm'n, Minutes of Aug. 23, 1961, attachnent 1. California would also litigate the problem of Carson River water allocation if negotiations failed. Id., Minutes of Dec. 13-14, 1961, at 7.

142 King, Interstate Water Compacts, in Water Resources aNd the LAW 355, 384 (1958): "The cases demonstrate the uncertainty of result, the lack of finality to the dispute, the time-consuming and interminable bitigation and re-litigation, the evident dissatisfaction of the partics with the adjudicated results as evidenced by the constant resort to the court subsequent to the initial decision, and the lack of continuing administrative supervision under the court decrees. The money and tine expended are very substantial, and the issues so intricate ... that the court is ill-equipped to deal with these disputes." Rehef is withheld unless the complaining state can show actual or inmediately threatened injury. In addition, the Supreme Court has generally refused to settle disputes involving division of water for potential future uses. See Colorado v. Kansas, 320 U.S. 383 (1943); King, supra at 379, 383; State of Californta Office of the Atr'y Gen., Principles and Methods Used in thie Distribution Between States of INTerstate Waters 1 (1956).

143 U.S. Cosst. art. I, § 10, cl. 3 provides: "No State shall, without the Consent of Congress, ... . enter into any Agreement or Compact with another State. .. ." Altbough this language appears clear and inclusive, there is dispute among authorities as to preciscly what type of agreement or compact requires Congressional approval. See generally King, supra note 142 , at 357-59.

144 See Colorado v. Kansas, 320 U.S. 383, 392 (1943).

145 See, e.g., King, supra note 142 , at 422 . See also ZnMarernann and Wendets, The InTERSTaTe COMPPact SINCE 1925 103-12 (1951); Frankfurter and Landis, The Comzact Clause of the Constitution-A Study in Interstate Adjustments, 34 YAxE L.J. 685 (1925).

146 Lake Tahoe Area Council, Interstate Compacts (undated memorandum). 
commission in $1955^{\mathbf{1 4 7}}$ to negotiate and draft a compact allocating water, including that of Lake Tahoe and the Truckee River, between the two states. ${ }^{148}$ The Congress gave consent to the compact negotiations in the same year, providing for appointment of a federal representative to participate in the negotiations. ${ }^{149}$ The consent statute, however, requires that the compact be ratified by the legislature of each state and by Congress before it becomes effective. ${ }^{150}$

The first meeting of the Joint California-Nevada Interstate Compact Commission $^{151}$ was lield in January, 1956, but actual negotiations did not begin until July, 1958. The commission collected factual and engineering data and reviewed legal materials during the first two and one-half years

147 The State Engineers of Nevada and California discussed the advantages of a compact in 1951, but were unable to obtain legislative consent until 1955. "It is the opinion of those closely associated with the Nevada political scene that the desire for a compact was related to the need to facilitate construction of the Washoe Project of the United States Bureau of Reclamation by resolution of the water riglit problems of the Truckee-Carson River system." Jonnt Compact Conma's, Background Imforaration on the CaL.-Nev. INTERSTATE CONCPACT Negotiations 2-3 (1961).

148 See CaL. Govt. Code §§ 8130-39; Nev. Rev. Stats. ch. 538, §§ 538.270-538.410 (1961). The only limitation on the scope of the compact commission's activity is that the compact formulated must relate to the distribution and use of the waters of Lake Tahoe, and the Truckee, Carson, and Walker Rivers. Allocation of water from the Carson and Walker Rivers is included within the scope of the proposed compact because both the Newlands and Washoe Projects use water from these streams.

It might be noted that this is the first interstate compact involving allocation of waters of three separate rivers. Jonnt Compact Comar'n, Report of the Drafting Conmutree 2 (1963).

14969 Stat. 675 (1955). The role of the federal representative includes the duty to assure that the complete range of federal and national interests is considered in the negotiations and to make quarterly reports to the President through the Director of the Bureau of the Budget concerning the status of compact negotiations, together with his analysis, recommendations, and clearance drafts. Legal questions relating to the position of the United States are subinitted for decision to the Attorney General, through the Bureau of the Budget. In addition to independent counsel and technical consultants, the representative is expected to consult with and represent the interests of the Departments of Agriculture, Commerce, Health, Education, and Welfare, Interior, Justice, and Labor, and the Federal Power Conlmission and the Department of the Army (Corps of Engineers). After final clearance of the proposed compact provisions by the Bureau of the Budget and the President, the representative signs the compact and transmits the draft to the Congress for legislative approval. See Bureau of tale Budget, Gume to Federal Participation in Interstate Compact NegotiaTiows (undated).

15069 Stat. 675 (1955); see Cad. Govt. Code $§ 8137$; Nev. Rev. Stat. ch. 538, § 538.390 (1961).

151 The menibership of the conumission consists of seven voting members from each state, appointed by the state governors, six of whon are required to be residents of the compact area. The federal representative, appointed by the President, serves as chairman, althougl without vote. See Cal. Govt. Code § 8132; Nev. Rev. STat. ch. 538, § 538.390 (1961). 
of its operation, and working committees were appointed for problem investigation..$^{152}$

The commission devoted its initial attention in the negotiations to the Lake Tahoe basin, and by mid-1961 agreement was reached on statutory language embodying the principles determined by the negotiators. ${ }^{153}$

In July of 1962 the director of the California Department of Water Resources expressed concern in a letter to the compact commission about the slow progress of the negotiations. ${ }^{154}$ He pointed out that the six years of proceedings had cost in excess of 600,000 dollars, and that the California legislature had requested a report for budget justification detailing the problems and issues resolved by the commission and the problems and issues not yet agreed upon. The director urged the commission to complete a compact draft by the summer of 1963 and to terminate negotiations at that time. ${ }^{155}$ In response, the commission prepared a special report containing the specific statutory language agreed upon with respect to the Lake Tahoe basin. ${ }^{156}$ The compact draft provides for construction at the lake's outlet ${ }^{157}$ of an overflow weir which is expected to result in a narrower range of fluctuation of lake level ${ }^{158}$ and to produce an additional 7,500 acre-feet of water ${ }^{159}$ without affecting downstream

152 Jonnt Compact Comar's, Report of the Drafting Conamtree 1-2 (1963). An Engineering Committee was appointed in early 1956 and a legal committee in late 1956. See Joint Compact Comm'n, Minutes of Jan. 17, 1956, at 4-5; Minutes of Dec. 21, 1956, at 6. A Definitions Committee was formed in 1958, followed shortly by the creation of the Lake Tahoe Water Problems Committee. Id., Minutes of Jan. 16, 1958, at 9-10; Minutes of May 20,1958 , at 11-12. The water problems committee operated on a formal basis; minutes of proceedings are available for its two year life. A drafting committee was established in late 1959, composed of the legal counsel for the state commission and the legal counsel for the federal representative. $I d$., Minutes of Nov. 4, 1959, at 7. Working committees, formed for each of the three river basins involved in the compact negotintions, are still operating.

153 Jonnt Compact Conam's, Report of the Drafting Conomitee 3 (1963).

154 See Joint Compact Comm'n, Minutes of Sept. 12, 1962, attachment 1.

155 The director added: "If a compact cannot be consummated within the above period, .... it seems doubtful that further negotiations along the same lines will be productive." Ibid.

156 See Jonnt Compact Conox's, Report of the Drafting Commirtee (1963). A draft of proposed compact tenns as of 1961 relating to the Lake Tahoe basin is reproduced in Compremenstve Study 133-34.

157 JonNT Compacr Comm's 7. Construction is made subject to the consent of the Umited States. The cost of installation is borne equally by the two states.

158 Cal. Compact Conar's, A Résumé of the Problears of the Cal.-Nev. Interstate Compact Negotiations 7 (1961).

150 Installation of the weir had been suggested by the Corps of Engineers in 1942. Joint Compact Comm'n, Lake Tahoe Water Problems Comm., Minutes of July 3, 1958, at 3. The commission accepted 7,500 acre-feet annually as the amount of new water to be made available by construction of the weir upon recommendation of a working committee, although a representative of the Corps of Engineers had stated earlier that overall benefits of the wcir could not be determined in the absence of very specific criteria as to how the lake would be 
flow. ${ }^{180}$ The commission allocated a gross diversion of 34,000 acre-feet to the Tahoe basin, of which Cahiorma is to receive 23,000 acre-feet and Nevada 11,000 acre-feet. ${ }^{101}$ The allocation is contingent on the requirement that the return flow from the gross diversion not be transported from the Lake Tahoe-Truckee River basin. As an alternative to the gross diversion, the permanent compact commission is required at the request of either state to determine whether it is "engineeringly feasible" to measure allocation on a net depletion basis. If measurement is possible, the net depletion method shall be employed in lieu of the gross diversion. The depletion method was originally suggested as-a compromise between those interests contending for a gross allocation and those contending for unlimited consumptive use of water within the basin. ${ }^{162}$ While the term "net depletion" seems inadequately defined in the proposed compact draft, ${ }^{163}$ this method contemplates that existing uses of water by

operated with the weir in place. See id., Minutes of Sept. 18, 1958, at 6; Minutes of Aug. 23, 1960, at 11 .

It was discovered in 1962 that the natural rim of the lake has been lowered from 6,223 feet to 6,222.8 feet by erosion. Construction of the weir will prevent the flow of water from the lake when its level is about two-tenths of a foot higher than at the present time. Tahoe Daily Trihune, Aug. 12, 1963, p. 1, col. 8.

160 Bureau of Rectamatton and Untted States Army Corps of Engineers, Report on Late Tamoe Operation Studies 11 (1959).

161 It was initially suggested by the Nevada commission member representing downstream interests that water be developed for Lake Tahoe use by cutting the rim of the outlet one foot, installing an overflow weir, and buying certain water rights in Echo Lake. These measures would result in a water supply for the basin of 18,000 to 19,000 acre-feet per year, according to the representative. Water developed from these measures above the amount allocated to the Tahoe basin should be equitably allocated between the two states. See Joint Compact Comm'n, Lake Tahoe Water Problems Committee, Minutes of July 21, 1958, at 2-4. The proposal to cut the outlet rim was considered extreme by a fellow Nevada commission member, who pointed out that dropping the outlet by one foot would produce about 120,000 acre-feet of water, while the maximum estimated future requirements of the basin were at that time considered to be 25,000 acre-feet, representing approximately 2.4 inches of Lake Tahoe storage space. Id., attachment 1. On the other hand, an "advisory group" of lakeshore property owners recommended to the water problems committee that unlimited appropriation of water for domestic and recreational uses be permitted to Lake Tahoe residents without regard to downstream allocations. See id., Minutes of July 8, 1959, at 5-7. (Nevada suggested of gross allocation of 15,000 acre-feet); Minutes of Sept. 2, 1959, attachment 1 (suggestion by Cahfornia commissioner that the largest of a gross allocation of 20,000 acre-feet, or 11,000 acre-feet on a net depletion basis, be allowed). A special subconmittee was established to arrive at a maximum reasonable diversion figure for the Tahoe basin. This subcommittee recommended the 34,000 acre-feet gross diversion figure later adopted in the compact. Sce id., Minutes of Feb. 1, 1960, at 2-3, 7 .

$162 I d$., Minutes of July 8,1959 , at 8.

163 Net depletion is defined in the compact draft as: "the loss of water at the outlet of Lake Tahoe attributable to the consumptive use of water within the Lake Tahoe Basin from uses of water commencing after - 19-, and after deducting therefrom any increase in runoff to Lake Tahoe or decrease in the consumptive use of the waters of the Lake Tahoe Basin resulting from changes in land uses occurring subsequent to - Jorrs 
basin residents would be recognized and permitted to continue. ${ }^{104}$ In addition, the compact draft establishes a net depletion figure of 7,500 acre-feet, which is the amount of new water expected to be produced by construction of the weir. This amount of water is granted to the Lake Tahoe area to be used for any purpose without a limitation with respect to return flow-i.e., use of water would be permitted until the outflow of the lake was depleted by 7,500 acre-feet annually. ${ }^{105}$ It las been estimated that from fifty to seventy percent of the water used in the Lake Talioe basin returns to the lake in sewage and waste flow. ${ }^{100}$ Assuming a seventy percent return flow, 25,000 acre-feet of water could be used before a net depletion of 7,500 acre-feet occurred. There is evidence that return flow rates may be increased in the future through reduction in evapo-transpiration losses presently occurring, the reduction to be accomphished by clearing vegetation from land for area development. ${ }^{107}$ If relatively high return flow rates of eighty percent were reached, 37,500 acrefeet of water could be used within the basin before a net depletion of 7,500 acre-feet occurred. This figure represents an increase over the gross diversion of 34,000 acre-feet allowed in the compact. The net depletion method of allocation was strenuously supported by California representatives and vigorously opposed by Nevada representatives. The reason for this controversy is not clear, since it appears untikely that the depletion method will result in a greater allocation to the Tahoe basin than the 34,000 acre-feet gross diversion. Nevertheless, the depletion alternative was recommended only after extended disagreement which at

Compact Comas's, Report of the Drafting Comantitee 8 (1963). The importance of the dates to be filled in by the committee at some time in the future is obvious. The later the date selected, the more favorable it is to the littoral landowners, since uses recognized as of the date selected are not included in net depletion measurement.

164 Ibid. See also Joint Compact Comm'n, Minutes of Aug. 23, 1960, at 10-11.

165 For an explanation of the method, see Joint Compact Comm'n Lake Tahoe Water Problems Committee, Minutes of July 8, 1959, at 8; Joint Compact Comm'n, Minutes of May 20, 1960, at 10-13.

166 Some studies indicate that about $70 \%$ of the domestic water used in the basin returns to the lake as sewage flow. See COMPREHENsive Study 39; however, the compact commission based its allocation of water on a $50 \%$ return flow, meaning that half of the water used in the basin will eventually find its way back to Lake Tahoe for consumptive use downstream in Nevada via the Truckee River. Tahoe Daily Tribune, August 12, 1963, p. 1, col. 7; Joint Compact Comm'n, Minutes of Feb. 27-28, 1961, at 39.

167 See Cat. Compact Commin, Background Inforasation on the Cal.-Nev. Interstate Compact Negottations 5 (1961); Joint Compact Comm'n, Minutes of May 20, 1860 , at 10-12. Vegetation absorbs large quantities of water. Replacement of natural vegetation by housing subdivisions, for example, decreases the vegetative consumption of water in the area but is somewhat offset by consumptive use and evaporation caused by construction of the subdivision. Clearing of land may result in an overall net gain of water available for human use. 
one point threatened a change in the proposed basic administrative machinery of the conpact. ${ }^{188}$

The recommended provisions permit pumping from Lake Tahoe in periods of drought for the benefit of downstream users for domestic and other essential purposes ${ }^{169}$ when it is determined by the permanent commission that no other water is available. ${ }^{170}$ This worthwhile provision is

168 The administrative article of the compact provides that the permanent commission is to consist of five members from each state, each state is to have one vote on a unit basis, and all commission decisions require the concurring votes of both states. A general arbitration section provides that in cases of tie votes, the matter in question may be referred to the federal representative for a binding decision. Alternatively, either state may submit the matter to arbitration. Each state selects one arbitrator; the two select a third. The decision of the majority of the three arbitrators is binding upon the commission. See JonNr Com-

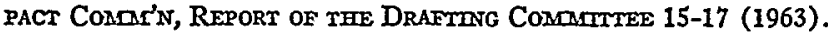

The depletion provision, as originally drafted, provided for a special voting and arbitration procedure. Before the depletion method of allocation could be used, the vote was required to be unanimous. If not unanimous, the question was to be referred to a panel of three engineers experienced in the field of hydrology if a majority of the ten commission members, voting individually rather than by state units, favored the depletion method. The engineers selected then were to determine conclusively whether the depletion method could be employed. Thus, a tie vote between the states would not be sufficient to require arbitration as it would under the general administrative provision; at least six of the ten state commissioners had to agree to the special arbitration procedure. See Joint Compact Comm'n, Minutes of July 11, 1960, at 11-13; Minutes of Nov. 3-4, 1960, at 10-13, and attachment 1 . In addition, the membership provision in the administrative section of the compact provided that the five Nevada representatives were to represent selected areas within that state. While no member was designated as responsible for the Tahoe basin, one commissioner was to be a representative at large. After the commission agreed to this membership clause, Nevada sought its amendment, asking for seven members on the permanent commission in order to achieve a better area representation. See id., Minutes of Oct. 13, 1961, at 3-8 and attachment 1. Cahifornia opposed any change in membership as to number on the ground that special arbitration of the depletion method of allocation would be jeopardized-since seven commissioners would have to agree to arbitration instead of six. Cahformia also opposed the numerical imbalance of members between the states which would result from the amendment. In addition, Califorma opposed change in the areas to be represented by the commission representatives because Califorma had presumed that the independent member-at-large would not represent any specific interests contrary to those of the Lake Tahoe basin and might therefore vote with the Califorma members. The requisite majority vote to require arbitration of the depletion method of allocation would thereby result. See id., Minutes of Feb. 27, 1962, at 10. Finally, however, Nevada was allowed to amend the original membership clause to eliminate the representative-at-large without providing that any Nevada commissioner represent the Lake Tahoe basin. In return, special arbitration of the depletion method was eliminated and became subject to the general arbitration provision in the administrative article of the compact. Id., Minutes of Sept. 12, 1962, at 9-11.

100 Pumping is to be allowed for municipal, samitary, and essential stockwatering purposes as well as for domestic purposes. Irrigation is purposely excluded. Pumping is to be done under the control and supervision of the permanent commission. Water pumped is not charged to the allocation of water made to the Lake Tahoe basin by the compact. Jornt Compact Commsn, Report of the Drafting Comamtee 16 (1963).

170 Ibid. 
intended to eliminate controversy on pumping such as occurred during dry periods in the 1920's and 1930's, ${ }^{171}$ and to obviate the need for agreements between littoral and downstream interests regulating pumping.

The compact draft contains a clause specifying that the storage rights in Lake Tahoe are to be exercised alone or in conjunction with those of other reservoirs in order to minimize the periods of high and low water elevations, if this can be accomphished without adverse effect on the rights of beneficial users downstream. ${ }^{172}$ This hortatory provision is directed at the United States and represents a rather innocuous substitute for earlier pressures by Lake Tahoe landowners to set the upper limit of the lake at 6,228.5 feet above sea level. ${ }^{173}$ The commission abandoned the idea of lowering the upper lake level, ${ }^{174}$ apparently because of opposition from downstream interests and because of the probable difficulty in obtaining the approval of the United States. ${ }^{175}$

The compact draft states that the right of the United States or its agents to store water between 6,223 and 6,229.1 feet in Lake Tahoe and to release stored water for downstream uses is "ratified and confirmed." ${ }^{\prime 176}$ Nevertheless, it appears that the allocation of water to the Lake Tahoe basin depletes the amount of water stored in the lake and reduces the amount available for flow downstream. Since both the rights to store and to release all water which would flow over the natural rim in the absence of the dam at the lake's outlet are claimed by the United States, apparently without regard to littoral uses, it seems clear that the allocation, at least as to the part exceeding the present uses in the basin, is to be taken from the water claimed by the United States. This fact was pointed out periodically during the negotiations by the Nevada commission member representing downstream interests. ${ }^{177}$ Representatives of the United States dechined to indicate approval of suggested compact allocations, and dechined to state what amount of water could be allocated to the Lake Tahoe basin "without infringing in any measurable degree upon the prior vested rights that the United States claims."178 A Bureau

\footnotetext{
171 See note 79 supra and accompanying text.

172 Joint Compact Coman's, Report of the Drafingu Committee 7 (1963).

173 Joint Compact Comm'n, Lake Tahoe Water Problems Committee, Minutes of Sept. 18, 1958, at $3-4$.

174 Joint Compact Comm'n, Minutes of Sept. 3, 1959, at 11.

175 The compact must be ratified by the United States to become effective. See note 150 supra and accompanying text. Inclusion of a provision lowering the level of the lake would probably have resulted in opposition by the Bureau of Reclamation and consequent failure of Congressional approval of the entire compact.

176 JoInt Compact Comar's, Report of the Drafing Comanties 7 (1963).

177 See Joint Compact Comm'n, Lake Tahoe Water Problems Committee, Minutes of Sept. 2, 1959, at 3, 5; Minutes of May 20, 1960, at 12.

178 Id., Minutes of Sept. 2, 1959, at 5-6.
} 
of Reclamation representative stated that the compact commission would be called upon to prove to the United States that any proposed water allocation would not infringe on rights or property of the United States. ${ }^{179}$ If anything claimed by the United States as its property were taken from it, compensation would be demanded. ${ }^{180} \mathrm{It}$ was suggested by a Cahiforma commission member that the right to pump from Lake Tahoe during dry periods for the benefit of downstream users might be considered as compensation for the "sniall reduction in the amount of usable water from the Lake Tahoe storage. ${ }^{2181}$ While negotiations proceeded without further consideration of the problem, it is apparently not yet settled within the commission. Although it was stated by a California deputy attorney general at a meeting held in November 1963 that "there has been almost complete agreement upon the Lake Tahoe basin, including the 34,000 acre-feet allocation to the lake . . .,, 182 the Nevada commission representative for downstream interests contended at the same meeting that the commission's allocation to the Lake Tahoe basin failed to consider that the United States, in the Truckee River Agreement, had allocated some sixty-nine percent of the divertible flow from Lake Tahoe to Washoe County. He believed the United States would not approve any encroachment upon this diversion, and he urged further consideration of the matter by the commission. ${ }^{183}$

The compact allocation of water to the Lake Tahoe basin and regulation of lake levels raises the problem of how best to bind the United States with respect to these provisions. The United States has consistently taken the position that it will not be a party to western water compacts. ${ }^{184}$ The United States has made contracts with states in the past, however, the validity of which have been judicially recognized. ${ }^{185}$ While it may nevertheless be open to question whether the continued compli-

179 Id., Minutes of Aug. 4-5, 1959, at 10; Minutes of Sept. 2, 1959, at 6.

180 Ibid.

181 Ibid.

182 Id., Minutes of Nov. 19, 1963, at 14.

183 Id. at 15 .

184 Stinson, Some Legat Principles Bearing on Federal Interests in the Proposed Nev.-Cal. Compact, Mearoranduar to Nev.-Cat. Compact Federal Representative 7 (1956) ; Joint Compact Comm'n. Minutes of Sept. 22-23, 1960, at 7. The federal government often participates in an advisory capacity without vote in the permanent compact functions; such procedure will be followed with the California-Nevada compact. Limited participation is to be distinguished from the very infrequent situations wliere the United States is a full partner in the compact, with reciprocal rights and obligations. See generally Hearings on a Bill to Grant the Consent of Congress to the Delaware River Basin Compact Before a Subcommittee of the House Committee of the Judiciary, 87th Cong., 1st Sess. 27-35, 70-74 (1961).

185 See Searight v. Stokes, 44 U.S. 151 (1845); cf. Walsh v. Columbus, Hocking Valley \& Athens R.R., 176 U.S. 469 (1900). 
ance of Congress under such a contract could be enforced against its will, ${ }^{186}$ a contract remains the only available method for inducing federal compliance. It does not seem likely that Congress, after agreeing to be bound by specific compact provisions, would reverse itself without compelling reason. Interstate compacts have in the past included various limitations which are to bind federal agencies; the limitations are then embodied in the final consent bill. ${ }^{187} \mathrm{~A}$ representative of the Department of Justice suggested to the California-Nevada Interstate Compact Commission that this procedure be adopted, ${ }^{188}$ and the California commission has stated that it will insist that the United States be bound by selected compact provisions, including lake levels. ${ }^{180}$ If the United States should refuse to recogmize and be bound by the provisions allocating water between the two states, the entire compact might well fail, and the states would probably resort to litigation. At the very least, disapproval of the basic allocation would result in prolonged extension of compact negotiations, already in the ninth year.

The duration of the compact negotiations to date has understandably led to impatience by governmental and private groups. ${ }^{100}$ Governor Brown of Califorma called for consummation of the compact by June 1, 1964 , in a letter to the compact commission. ${ }^{101} \mathrm{He}$ indicated that if compact negotiations were not completed with respect to Lake Tahoe and all river basins concerned, the compact should include only Lake Tahoe and the Carson River basin, with continued negotiations for the Truckee and Walker Rivers. ${ }^{102}$ However, Governor Sawyer of Nevada and the Nevada commission are unwilling to conclude a compact covering Lake Tahoe which does not also include the Truckee River. ${ }^{103}$ At the end of 1963, Truckee River negotiations were apparently deadlocked on the issue of water allocation. ${ }^{194} \mathrm{~A}$ completed compact acceptable to both states may require several months' time beyond the June, 1964 deadline. It would

186 See Zmomeracann and Wendeli, The Interstate Compact Since 192564 (1951). U.S. Const. art. I, $\S 10$, cl. 1, prohibiting the impairment of contractual obligations, does not apply to the federal government.

187 Strnson, Some Legal Prniciples Beardag on Federat Interests in the Proposed Nevada-Catifornta Compact, Memorandum to Nevada-Calmornia Compact Federax Representative 9 (1956). This procedure was adopted, for example, in the Boulder Canyon Project Act of 1928, 45 Stat. 1062 (1928), 43 U.S.C. $\$ 617$ (g) (1958), the Republican River Compact, 57 Stat. 86 (1943), the Belle Fourche Compact, 58 Stat. 94 (1944), and the Boulder Canyon Project Act of 1956, 70 Stat. 110 (1956), 43 U.S.C. $\S 620$ (m).

188 Joint Compact Comm'n, Minutes of Sept. 22-23, 1960, at 7.

180 Id. at $6-7$.

$190 I d$., Minutes of Feb. 27-28, 1961, at 15; Minutes of May 22, 1963, at 7.

191 Id., Mimutes of Nov. 19, 1963, attachment 3.

192 Ibid.

103 Id., Minutes of Dec. 13, 1963, at 11-12.

104 Id., Minutes of Dec. 13, 1963, at 3. 
seem that particular patience by the two states is required at the present time. Pressure-induced haste at this juncture may result in drafting errors or even jeopardize the entire compact. It is interesting to note that the average time duration for negotiating and concluding eighteen of the twenty-one interstate water compacts existing in 1958 was 11.9 years. ${ }^{195}$ The time lag between the final drafting of the agreement and completed ratification by all states and Congress accounted for eight of these years, although the average time between earliest state ratification to complete adoption was only one year. ${ }^{196}$ These statistics illustrate the inertia of the parties which in the past has delayed state ratification after the compact has been drafted. It is this inertia which could be most profitably attacked through the energy of the respective state governments. ${ }^{197}$

\section{IV}

\section{THE POLLUTION PROBLEM}

Both California and Nevada have sought for many years to prevent contamination of the surface waters of the Lake Tahoe basin in order to protect an important source of domestic water supply and to preserve the area's attractive recreational qualities. Since 1949 Nevada has by statute forbidden the direct discharge of sewage or sewage effluent ${ }^{188}$ into the lake, its tributaries, and the Truckee River; ${ }^{109}$ California, through

$195 \mathrm{King}$, Interstate Water Compacts, in Water Resources and THE LAW 353, 401.

196 Id. at $403-05$.

- 197 On May 2\%, 1964, it was reported that a committee of the compact commission had tentatively agreed that $75 \%$ of all surplus water developed on the Truckee River systein was to go to Nevada with $25 \%$ allocated to California. Additionally, Nevada and Califormia would split, on an $80-20 \%$ basis, the 155,000 acre-feet to be stored at Stampede Dam. These allocations were to be reviewed in 1985 and every five years thereafter in the event that the water requirements of the Truckee River basin increased. San Francisco Chronicle, May 27, 1964, p. 1, col. 3. A question later arose, lowever, concerning at what point the Truckee River water became "surplus," and to assist in the resolution of that question, two engineers were appointed by the commission to determine the quantity of water each state had been drawing from the Truckee River. Id., June 3, 1964, p. 27, col 5. By June 11, 1964, none of the separate committees attempting to draft acceptable agreenents for allocation of the water from the Truckee, Carson, and Walker Rivers lad arrived at a firm recommendation, so the Commission cancelled all future ineetings until such time as it received a final report on the allocation of water of at least one of the three rivers. Id., June 12, 1964, p. 27, col. 1 .

198 Sewage "effluent" is the term applied to waste after it has undergone treatment. Effluent quality varies greatly, depending upon the nature and extent of treatment.

199 See NEv. REv. STAT. ch. 445, \& 445.090 (1961). Water pollution control powers are vested in the State Board of Health. NEv. REv. STat. ch. 445, $\$$ 445.050, 445.060 (1961). The state attorney general, with the consent of the Governor, inust institute actions to prevent or restrain water pollution. NEv. REv. STat. ch. 445, $\$ 445.020$ (1961). The State Board of Health, acting under authority given in NEv. REv. STAr. ch. 445, \& 445.100 (1961), issued regulations in 1958 which require that a permit be obtained from the Division of Public Health Engineering before any construction involving sewage disposal or water supply is commenced within the Lake Taloe watershed. The applicant must provide infor- 
an administrative regulation issued by the Lahontan Regional Water Pollution Control Board, ${ }^{200}$ forbade, after $1952,{ }^{201}$ the discharge into surface waters of the Lake Tahoe and Truckee River watersheds of sewage not meeting United States Public Health Service standards for drinking water. $^{202}$ The California regulation was amended in 1962 to prohibit direct discharge of donuestic sewage, treated or untreated, into the lake or its tributaries. ${ }^{203}$

Between 1949 and 1953 the Tahoe City, North Tahoe, and South Tahoe Public Utility Districts and the Douglas County Sewer Improvement District No. One were created to collect, treat, and dispose of sewage. Collection and treatment facilities for each of these agencies were

mation including specifications of the proposed disposal system; site inspection is required; and certain minimum building requirements, such as lot size, must be met. STATE of NeVADA Departacent of Heatth, Division of Public Health Engineertng, Law Retating to Protection of Lake Tahoe Watershed and Regulations Ggverning Construction Involving Sewage Disposal and Water Supply in the Nevada Pgrtion of the Lake TaHoz Watershed 5-8 (1958).

200 California features a statutory division of functions between health agencies and water pollution control boards. If waste discharge threatens the public health, the State Department of Public Health must take immediate abatement action to protect the public. Cat. Headith \& Safety Code \& 5412. Under the Dickey Water Pollution Act of 1949, CaL. WATER CODE $\$ \S 13000-64$, power to formulate state-wide policy for the control of water pollution involving unreasonable effects on beneficial water uses falling short of a public health menace is vested in the State Water Quality Control Board. Operating under the state board are nine regional boards, whose primary function is to chiminate threatened or existing conditions of pollution. See generally Moskovitz, Quality Control and Re-use of Water in California, 45 CAIIF. L. REv. 586 (1957). The Lahontan Regional Water Pollution Control Board has jurisdiction over the California portions of the Lake Tahoe basin. The relevant state statutes allow cities and counties to impose additional restrictions on waste disposal not in conflict with state law and to declare, prohibit, and abate nuisances. Car. Water Code § 13001(a) \& (b); CaL. Health \& Safety Code § 5415(a) \& (b). The Placer County Health Department stated in 1958 that its policy in approving any sewage treatment works was to require that all possible efforts be made to keep sewage effluent on land. Lamontan Regional Water Pollution Control Board, Resolution 58-1, at 1 (1962). Ordinances of El Dorado County prohibit the discharge of domestic sewage into the surface waters of the county, and the county health department opposes discharge into any part of Lake Tahoe. Ibid. Thus, waste disposal in the California portion of the lake basin may be simultaneously subject to regulation and control by the Department of Public Health, the Lahontan regional board, and the county in which the disposer is situated.

201 Prior to 1949, a permit from the California State Department of Public Health was required for any discharge of wastes into state waters and for the construction and operation of waste treatment or disposal facilities. See former $\$ \$ 5410-45$, CaL. Healtu \& SAFETY CODE, repealed by Cal. Stat. 1949 ch. 1550, p. 2789, \& 1. The department long maintained the policy of not permitting sewage disposal directly into Lake Tahoe. See DEPT. OF Heatith, Educ., and Welfare, Public Health Service, Report on Water Pgltution CONTrol-NorthWESTERN LAHONTAN BASIN 35 (1953).

202 See Resolution 52-3 of the Lahontan Regional Water Pollution Control Board, reprinted id., appendix B. Public Health Service Drinking Water Standards are presented id., appendix $\mathbf{C}$.

203 Lahontan Regional Water Pollution Control Board, Resolution 58-1 (1962). 
completed and operation was commenced between 1954 and $1957 .{ }^{204} \mathrm{~A}$ fifth treatment system has recently been constructed to serve Incline Village. In each system, the treated sewage is sprayed on vegetation or run into ponds and ditches on land especially acquired for that purpose $;{ }^{205}$ the waste water evaporates or seeps into the ground.

The rapid population growth of the Lake Tahoe basin since $1956^{206}$ has been accompanied by an increasing public concern with respect to sewage collection, treatment, and disposal. Overloading of treatment facilities, the high cost and scarcity of additional land disposal sites, the inadequacy of individual cesspools and septic tanks, and the threat of pollution to the waters of Lake Tahoe and its tributaries ${ }^{207}$ led to a series of studies by various agencies to determine the extent and possible solutions of the problems. The first of these was conducted in 1958-59 for the South Tahoe Public Utility District. ${ }^{208}$ Four possible disposal methods to accommodate increased sewage were discussed: direct discharge into Lake Tahoe or its tributaries, export of treated effluent from the Tahoe basin, disposal by deep well injection, and increased land disposal by spreading or spray irrigation. Concerning the advisability of direct discharge, the study noted the unusual clarity and brilhance of Lake Tahoe water, and its low nutrient balance owing to the absence of nitrogen and phosphorus. Where nutrient rich domestic sewage was introduced into similar lakes, ${ }^{209}$ a process of "eutrophication"210 occurred characterized

204 The Douglas County Sewer Improvement District uses the treatment facilities of the South Tahoe Pubhic Utility District under a 1953 agreement between the two agencies. The Douglas County district contributed to the construction of the treatment plant and pays the South Tahoe unit an amount based on volume of sewage treated. An amendment to the agreement assigns a maximum quota of $1,000,000$ gallons per day of sewage to the Douglas County agency. See South Tamoe Pubitc Utmity District, Soutr Tamoe Sewerage Survey 49-51 (1959); San Francisco Chronicle, Sept. 26, 1963, p. 4, col. 1; Oct. 4, 1963, p. 1 , col. 4 .

205 Land for percolation ponds and trenches may be owned outright by the public utility district concerned. The South Tahoe Public Utility District utilizes in addition to its own seepage beds and large underground septic tanks about 250 acres of land leased from the United States Forest Service and operated under a special use permit allowing spray disposal of effluent on vegetation and storage in oxidation ponds. See Soutr Taдoe Pubcrc Uimity District, South Tafoe Sewerage Survey 43-46 (1959); Tahoe Daily Tribune, Sept. 30, 1963, p. 2, col. 1; Aug. 6, 1963, p. 1, col. 5 ; San Francisco Chronicle, Aug. 20, 1963, p. 1, col. 1 .

206 Permanent population increased from an estimated 2,850 in 1956 to 16,000 in 1963 , seasonally employed residents from 6,400 to 22,200 , and summer recreation residents from about 9,500 to 27,100. Tamoe Regional Plannang Conomassions of Nev. and Cad., Premomitara Regionax Plan (1962).

207 South Tahoe Public Utmity District, South Tafoe Sewerage Survey 1 (1959); Cat. Compact Coscar'n, Lake Tahoe Faces Water Problems 7-8 (1958).

208 South Tafoe Public Utrity District, South Tahoe Sewerage Survey (1959).

209 The study cites Lake Washington near Seattle as an example. Id. at 60-61.

210 "Eutrophication" is the process by which a lake changes from one of low biological activity (oligotrophic) to one of high biological activity (euthrophic). Id. at 61 . 
by excessive growths of plankton. High nutrient content eventually produces heavy growths of green or blue-green algae, frequently accompanied by excessively turbid water and masses of odorous and decaying scum. ${ }^{211}$ Because of probable eutrophication and permanent degradation of Lake Tahoe, ${ }^{212}$ the study recommended against direct discharge of effuent into the lake or tributary streams.

The study considered two possible export routes, the first by means of a pipeline over Echo Summit into the south fork of the American River in California, and the second via a pipeline over Daggett Pass to the Carson Valley in Nevada. Export by these routes was rejected because of the impossibility of meeting water quality requirements established by the Central Valley Regional Water Pollution Control Board ${ }^{213}$ and the Nevada State Department of Public Health.

Disposal of sewage by deep well injection, featuring a series of cased wells and pumps to force the effluent into the subsurface strata, was considered unacceptable because of problems with well clogging and because inorganic phosphorus would not be removed and could reach the lake with degrading effect. The study recommended that land disposal of treated effluent be accepted as the only practical alternative and that additional property be immediately acquired for that purpose. ${ }^{214}$ The study recognized the danger of phosphate enrichment incident to land disposal, with consequent eutrophication of the lake, and concluded that its recommendation would be open to future modification or rejection. ${ }^{215}$

A water quality study conducted in 1961 by the California Department of Public Health ${ }^{216}$ concluded that conditions of water quality in wells, lakes, and streams of the basin were not affected to any great extent by sewage disposal practices during the study period. It was noted, however, that the study was conducted after several years of subnormal precipitation, with lowered ground water tables and with the level of Lake Tahoe six feet below normal. Thus, a determination of the effectiveness of individual and community disposal systems during periods of heavy precipitation and runoff, when system failures are most likely to

211 Ibid.

212 Secondary reasons given were the possibility of raw sewage entering the lake during treatment plant discharges with resultant pollution of recreational beaches, the disagreeable aesthetic implications of sewage outfalls in the lake, and the hazard of setting an undesirable precedent. Id. at 62-63.

213 This regional pollution control board has jurisdiction over the American River which flows through Sacramento. See discussion note 200 supra.

214 South Tamoe Public Utimtry District, Soutr Tahoe Sewerage Survey 81, 138-

39 (1959).

215 Id. at 139.

216 Californta Dept. of Pub. Heatth, Buread of Samitary Engineertng, Lake tatioe BASIN WATER QUALITY SURVEY (1961). 
occur, could not be made. It was noted that a few individual household systems were failing, although overflows were not reaching nearby surface and well water, and that the South Tahoe Public Utility District's disposal facilities had overflowed into basin streams and meadows during peak Labor Day loading. A long range program for collection, treatment, and disposal was recommended. ${ }^{217}$

The most recent study ${ }^{218}$ on the problem of waste disposal was completed for the Lake Tahoe Area Council ${ }^{219}$ in mid-1963 by a team of five eminent scientists with backgrounds in sanitary engineering. ${ }^{220}$ In a comprehensive and thorough report, the scientists concluded that the clarity of the lake had been affected by nutrient build-up and that a continuation of existing disposal methods would result in a progressive deterioration of lake waters with possible eutrophication occurring in a matter of a few years. ${ }^{21}$ Disposal practices, however, were considered satisfactory from a public health standpoint. Thus, while nutrient rich run-off to the lake resulting from hillside spraying or underground leaching does not adversely affect lake waters for human consumption, the run-off does create an aesthetic threat which will eventually destroy the clarity and beauty of the lake. The scientists made three primary recommendations: (1) expansion of the five existing public sewerage agencies into an integrated regional disposal system; (2) removal of waste effluent from the Lake Tahoe watershed; and (3) continued interest in the problem of waste disposal by an agency or authority representing the entire basin. ${ }^{222}$ The scientists concluded that the best overall solution to assure protection of the lake and to avoid water losses in the Truckee River was to discharge highly treated effluent into the Truckee River. ${ }^{223}$

Publication of the 1963 waste disposal study was followed immediately by extensive publicity and acute public interest in the sewage problems of Lake Tahoe. In August of 1963 the Lake Tahoe Area Council invited the President's Water Pollution Control Advisory Board ${ }^{224}$ to

217 Id, at sviii.

218 CoMrprenenstve STUdy.

219 The study, completed at a cost of $\$ 125,000$, was financed by funds granted by the Max C. Fleischmann Foundation of Nevada to the Lake Tahoe Area Council.

220 P. H. McGauhey, chairman of this team of university professors, is the Director of the Samitary Engineering Research Laboratory, University of California at Berkeley.

221 CoMrprenensive StUdy 128. Professor McGauhey stated after completion of the study that the critical point of eutrophication could occur within ten to fifteen years. Tahoe Daily Tribune, June 17, 1963, p. 1, col. 5.

222 CoMIPREhensive Study 128-29.

223 Id. at 129. Consideration was also given to export from the basin to Nevada other than via the Truckee River and to possible discharge directly into Lake Tahoe if a largescale experimental program demonstrated that adequate nutrient removal to protect the lake was feasible.

224 This body was created in 1957 under the provisions of the Water Pollution Control 
visit the lake. Later in the same month, the El Dorado County Board of Supervisors approved a controversial permit requested by the South Tahoe Public Utility District for spraying treated sewage upon 144.5 additional acres of forest land. ${ }^{225}$ California members of the interstate compact commission adopted a resolution vigorously endorsing the scientists' study and expressing great concern over the serious threat to the lake posed by continued sewage disposal within the basin. ${ }^{220}$ In late September, the chief of the Nevada Bureau of Environmental Health announced that building permits on the Nevada side of the lake would not be issued until the sewage problem was solved, ${ }^{227}$ a position which was maintained for one week. ${ }^{228} \mathrm{~A}$ few days later the public liealth officer for El Dorado County found evidence of sewage contamination in several mountain streams draining into Lake Tahoe; new sewage connections on the California side of the lake's south shore were banned, temporarily halting construction of new buildings. ${ }^{229}$ The President's Water Pollution Control Advisory Board visited the lake from September 26 to September $28^{230}$ and subsequently passed a resolution urging that steps be taken to prevent further pollution. ${ }^{231}$ The investigation by the advisory board

Act, 62 Stat. 1155 (1948), as amended, 75.Stat. 204, 33 U.S.C. $\$ \S 466-466(\mathrm{k})$ (1961). In addition to providing for grants to states and municipalities for pollution control programs. and for construction of sewage treatment works, the Act includes provisions for action by the Secretary of Health, Education and Welfare to abate pollution of interstate waters which endangers the health or welfare of any person. Federal action may be initiated upon the request of the governor of a state or other specified state or local agencies, or upon the Secretary's own initiative. See 75 Stat. 204, 33 U.S.C. $\$ 466(\mathrm{~g})$ (1961).

225 San Francisco Chromicle, Aug. 20, 1963, p. 1, col. 1. The project, opposed by conservationists and some Tahoe lome owners, was passed by an affirmative vote of three of the five supervisors. The executive director of the Lake Tahoe Area Council favored granting the permit as an interim measure. Ibid.

226 San Francisco Chronicle, Aug. 22, 1963, p. 1, col. 2. The memhers urged removal of effluent from the basin "by any feasible means, including but not limited to export . . . either to the Truckee river or to basins otler than the Truckee river." Id., p. 17, col. 4.

${ }^{227}$ San Francisco Chromicle, Sept. 26, 1963, p. 4, col. 1; Oakland Tribune, Sept. 26, 1963 , p. 4, col. 1 .

${ }^{228}$ See San Francisco Chronicle, Oct. 4, 1963, p. 1, col. 4. The change of position was apparently caused by pressure from developers with heavy investments in building plans and property. $I d .$, p. 6 , col. 2. The crisis occurred because ten pending applications by developers for construction permits indicated an addition of over one million gallons per day to the 350,000 gallons per day of effluent then originating at the Nevada south shore. Over half of this linge increase is attributable to a twenty-six story, 1000-room annex to Harrah's Club, a new 475 unit apartment house, and a new casino-motel for Oliver's Club. Ibid.

${ }^{229}$ San Francisco Chronicle, Oct. 9, 1963, p. 1, col. 3. High bacterial counts apparently occurred because of malfunction of the South Tahoe Public Utility District's secondary treatment system.

230 San Francisco Chronicle, Sept. 27, 1963, p. 2, col. 5; Sept. 28, 1963, p. 1, col. 8. The visit included an investigatory learing on the matter.

231 San Francisco Chronicle, Nov. 11, 1963, p. 5, col. 4; Joint Compact Comm'n, Min- 
resulted in a warning conveyed to the Governors of California and Nevada that in the absence of efforts by the respective states to prevent further pollution, federal intervention under the Water Pollution Control Act ${ }^{232}$ might result. ${ }^{233}$

Spurred by the increasing public concern and publicity given to the pollution threat to Lake Tahoe and by the actions of the advisory board, Governor Sawyer of Nevada and Governor Brown of California met t $^{234}$ and issued a joint resolution recommending export of treated sewage from the basin by the fall of $1965^{\mathbf{2 3 5}}$

To facilitate export of treated sewage from the Tahoe basin, the South Tahoe Public Utility District proceeded with plans to construct a tertiary treatment plant intended to produce water sufficiently pure to be used for drinking purposes, ${ }^{236}$ althougll algae producing minerals would not be removed. ${ }^{237}$ Critics contend that the processed water will not be

utes of Nov. 19, 1963, attachment 2. The resolution called for a competent, permanent authority to maintain the needed water quality standards.

23275 Stat. 204, 33 U.S.C. $\$ \S 466-466$ (k) (1958).

233 San Francisco Chronicle, Nov. 11, 1963, p. 5, col. 4.

234 See San Francisco Chronicle, Nov. 12, 1963, p. 1, col. 3.

235 See Joint Compact Comm'n, Minutes of Nov. 19, 1963, attachment 1. The Governors also (1) recommended that the communities at the north end of the lake joimtly initiate a study to develop a long range program for sewage disposal; (2) recommended that the basin counties, with cooperation from both states, study (a) removal of garbage from the basin, (b) passage of compatible regulations concerning basin sewage disposal, (c) acquisition of water to replace exported sewage, (d) formulation of organizations to plan, finance, construct, and operate needed disposal facilities, and (e) development of plans for curtailing new sewerage until the disposal problem has been solved; (3) called for a signed interstate compact by June 1,1964 , thereby creating a bi-state agency with responsibility for overseeing unaintenance of water quahty; and (4) provided for appointment of a special representative from each state to work with local agencies in carrying out the Governors' program and to advise the Governors on the progress of the program. Ibid.

236 In 1961 the South Tahoe Public Utility District constructed a pilot plant employing the new trcatment system and spent two years analyzing its operation. Tahoe Daily Tribune, March 24, 1964, p. 1, col. 5. The system, known as the Pitcon process, employs a combination of activated carbon filtration and phosphate removal by alum coagulation. The system is described in Lake Tahoe, Sept. 30, 1961, p. 3, col. 1. Ground was broken for the permanent plant in June of 1964. Tahoe Daily Tribune, June 5, 1964, p. 1, col. 5. The total cost of $\$ 570,000$ was partially defrayed by grants of $\$ 260,000$ from the United States Public Health Service. The plant has been variously described as "a water treatment plant such as is used by most major U.S. cities," "the first of its kind in the U.S.," and as "the only one of its kind in the world." Tahoe Daily Tribune, March 13, 1964, p. 1, col. 7 ; May 5,1964 , p. 1, col. 2 ; June 5, 1964, p. 1, col. 4.

237 Tahoe Daily Tribune, March 24, 1964, p. 1, col. 8; Comprenensive Study 106, 126. The treatnient plant is intended to pave the way for export of highly treated water and is not intended to allow discharge of the effluent within the basin. However, it has been claimed that the tertiary treatment plant coupled with eighty acres of additional spray disposal land in the basin will dissipate harmful nutrients, minimizing seepage into the lake and giving Lake Tahoe waters "a three-year reprieve from the algae threateming their clarity." San Francisco Chromicle, May 31, 1964, p. 23, col. 6. 
suitable for human consumption, ${ }^{238}$ and officials of the utility district have been equivocal in statements made concerning its quality. ${ }^{230}$

During the nine-month period since the Governors' conference of 1963, progress toward meeting the 1965 export date set by the Governors has been slow. Selection of the export route has been the subject of heated recriminations and controversy. The possibility of discharging highly treated effluent into the Truckee River as suggested in the scientists' pollution report of $1963^{240}$ has apparently been abandoned because of strenuous opposition by downstream Nevada users of Truckee River water. ${ }^{241}$

238 Tahoe Daily Tribune, April 17, 1964, p. 1, col. 4; San Francisco Chronicle, June 5, 1964, p. 4, col. 6. The El Dorado county health officer, Dr. Quentin Bonser, clains that the Pitcon process will not remove all viruses and that drinking the water might result in contraction of a disease such as hepatitis. Ibid.

239 Officials of the South Tahoe Public Utility District have stated that the processed water will be "crystal clear and drinkable," and have claimed that river water, and even the water of Lake Tahoe itself, is less pure. Tahoe Daily Tribune, Feb. 21, 1964, p. 1, col. 5; May 8, 1964, p. 1, col. 5. On the other hand, the engineering consultant for the utility district, under close questioning by reporters, stated that the water was safe to drink and could be used for bathing or swimming, but that it had harmless ingredients which kceps it out of the drinking water category. Tahoe Daily Tribune, March 6, 1964, p. 1, col. 7.

240 See text accompanying note 223 supra.

241 The cities of Reno and Sparks, Nevada, entered protests in July of 1963 to discharge of effluent into the Truckee. Joint Compact Comm'n, Minutes of July 16, 1963, at 8-9; Tahoe Daily Tribune, Aug. 21, 1963, p. 1, col. 7; Aug. 28, 1963, p. 1, col. 1. In October, Washoe County, Nevada, and the city of Reno passed resolutions opposing direct discharge of sewage effluent into Lake Taloe or the Truckee River if the water quality for recreational and drinking purposes would be thereby threatened. Joint Compact Conım'n, Minutes of Oct. 10, 1963, attachments $2 \& 3$. W. W. White, Chief of the Nevada Bureau of Environmental Health, has expressed objections to effluent discharge into the Truckee on grounds of lack of dependability of treatment processes and cost of protecting public health. Letter from W. W. White to authors, Jan. 23, 1964. William Warne, Director of the California Department of Water Resources, noted that while the city of Sparks, Nevada, opposes discharge of sewage effluent into the Truckee, that city intends to discharge effluent from its own new treatment plant into the river. Tahoe Dailly Tribune, June 16, 1964, p. 1, col. 1. Reno and Sparks have long discharged sewage into the Truckee. In 1953 it was noted that effluent discharge by these cities constituted a health hazard to down-stream users at Wadsworth and Fernley, Nevada, because the Reno treatment facility removed only about $70 \%$ of organic matter from sewage, while the dilapidated and badiy overloaded treatment plant at Sparks resulted in discharge of nearly raw sewage into the river. See PuBLIC Heartr Service, U.S. Dept. of Healtr, Edtcatton, and Wetfare, Report on Pollutton Controt, NORTHWESTERN LAHONTAN BASIN 10, 26, 71 (1953).

There seems to be no rational objection against discharge of treated sewage into the Truckee if it can be clearly slown that the discharge meets the drinking water standards required by the United States Public Health Service. While phosphate and nitrate rich effluent will continue to be an aesthetic threat to Lake Tahoc, these minerals do not affect drinking water quality. The refusal by Nevada residents and officials to allow discbarge into the Truckee appears particularly indefensible in light of the insistence by Nevada water users that sewage effluent exported fron the Lake Tahoe basin must be replaced to protect their interests. See text accompanying note 266 infra. As the director of the California 
Primary attention was given to export of South Tahoe sewage over Echo Summit to the south fork of the American River in the vicinity of Lake Audrian, a route proposed in 1959 by the South Tahoe Public Utility District. ${ }^{242}$ Because of lower cost this route was favored over other suggested routes. ${ }^{243}$ The South Tahoe Public Utility District's board of directors requested the Central Valley Pollution Control Board, the agency charged with pollution control over the American River, to set standards of water quality for exported sewage. ${ }^{244}$ Strong opposition immediately developed to the American River export plan by downstream residents. ${ }^{245}$ The California Department of Fish and Game expressed doubt that the anticipated waste characteristics would assure the necessary degree of protection to fish, wildlife, and recreation. ${ }^{246}$ Two county agencies, the El Dorado Irrigation District and the El Dorado Water Agency, also expressed their opposition to the route. The water agency feared that exported water would be totally lost to the Tahoe basin and would adversely affect the basin's water allocation ${ }^{247}$ agreed upon by the interstate compact commission..$^{248}$ The agency felt that a system of exchange water credit might be arranged if the sewage were exported to Nevada, thereby preserving intact the basin's allocation. ${ }^{249}$ The El Dorado Water Agency appealed directly to Governor Brown to withdraw the 1965 export "deadline" established at the 1963 Governor's conference. ${ }^{260}$ The strangest opposition came from the El Dorado Irrigation

Department of Water Resources noted, "the re-use of sewage effluent, like atomic power plants, raises 'emotional disturbances." Tahoe Daily Tribune, June 16, 1964, p. I, col. 1. Emotional reactions complicate immeasurably the sewage export problem at Lake Tahoe.

242 South Tahoe Public Utirity District, South Tahoe Sewerage Survey 63 (1959).

243 The estimated cost of the Echo Summit plan is $\$ 1.25$ million, compared to $\$ 1.65$ million for a pipeline over Daggett ${ }^{\prime}$ Pass to the Carson Valley and $\$ 3.38$ million for a tunnel to the Carson Valley. In addition, projected annual costs are lower for the Echo Summit route. Tahoe Daily Tribune, March 6, 1964, p. 1, col. 6; April 2, 1964, p. 1, col. 6.

244 Tahoe Daily Tribune, March 20, 1964, p. 1, col. 6.

245 Tahoe Daily Tribune, April 1, 1964, p. 1, col. 4.

246 Tahoe Daily Tribune, April 17, 1964, p. 1, col. 6.

247 Ibid.

248 See note 161 supra and accompanying text.

240 Tahoe Daily Tribune, April 17, 1964, p. 1, col. 6. Thus, exported sewage used for irrigation in Nevada would not be charged as a use by the Tahoe Basin and would not deplete the 34,000 acre-feet of water allocated to the basin by the Interstate Compact Commission.

250 Tahoe Daily Tribune, April 7, 1964, p. 1, col. 4. No affirmative response by Governor Brown to this request has been reported. The primary reason for the appeal appears to have been concern over possible export to the American River, since the same agency had earlier adopted a resolution recommending export of effiuent. See Joint Compact Comm'n, Minutes of Nov. 19, 1963, attachment 4. A second reason for the request to the Governor was a desire to see export financed entirely by state and federal funds rather than by the 
District. It was feared that if the Central Valley Pollution Control Board announced high standards for discharge of effluent into the American River, hardship and expense would be created for the irrigation district, since the effluent it presently dispatches to the river is not subjected to as high a degree of treatment as that of the South Tahoe Public Utility District. ${ }^{251}$ Predictably, the Central Valley Pollution Control Board unanimously decided that sewage effluent from South Tahoe could not be introduced into the Anjerican River. ${ }^{252}$

With the possibility of export across Echo Summit foreclosed, the only route available, other than removal via the Truckee River, is across Daggett Pass into the Carson Valley in Nevada. The Chief of the Nevada Bureau of Environmental Health stated that effluent from the South Tahoe Public Utility District's tertiary treatment plant is acceptable for export to the Carson Valley, ${ }^{253}$ where it will be used for irrigation purposes. ${ }^{254}$ This route, while not the most economical, ${ }^{265}$ has the advantage of being presently unopposed by inhabitants of the receiving area. While the South Tahoe Public Utility District has not expressed enthusiasm for the route, ${ }^{258}$ it is meeting periodically with the Douglas County sewer agency to negotiate export to the Carson Valley. ${ }^{257}$

The controversy over the particular export route must not be allowed to obscure the basic necessity for export. The paramount public interest in maintaining the lake in its natural state demands that the export requested by the Governors of Nevada and California be accomplished at

South Tahoe Public Utility District, an agency supported by basin taxpayers. Ibid.; see also Lake Tahoe Area Council, Lake Tahoe, April 15, 1964, p. 1, col. 2.

251 Tahoe Daily Tribune, April 17, 1964, p. 1, col. 4. The agency feared that about $\$ 3$ million would have to be spent by it for treatment facilities adequate to produce effluent meeting the new standards.

252 Tahoe Daily Tribune, April 17, 1964, p. 1, col. 4.

253 Tahoe Daily Tribune, Feb. 21, 1964, p. 1, col. 5; Joint Compact Comm'n Minutes of Jan. 10-11, 1963, at 20.

254 Tahoe Daily Tribune, June 11, 1964, p. 1, col. 3.

255 See note 243 supra.

${ }^{256}$ See Tahoe Daily Tribune, April 7, 1964, p. 1, col. 4; Lake Tahoe Area Council, Lake Tahoe, April 15, 1964, p. 1, col. 2, at 4, col. 2.

257 Tahoe Daily Tribune, June 11, 1964, p. 1, col. 2; June 17, 1964, p. 1, col. 8. Studies by various agencies on water and pollution matters continue. The Bureau of Reclamation has just completed a $\$ 90,000$ reconnaissance survey, financed jointly by the Bureau and Placer and El Dorado counties, on water import needs of the Tahoe basin througb the year 2010. One of the primary conclusions of the report is that more study is needed. See Tahoe Daily Tribune, June 4, 1964, p. 1, col. 8; June 22, 1964, p. 1, col. 5. Several plans for water import are considered, including diversions by tunnel from the American River, Twim Lakes Reservoir, and the upper Rubicon River to the upper Truckee River. Tahoe Daily Tribune, April 15, 1964, p. 8, col. 1. The Max C. Fleischunann Foundation of Nevada has made a special grant of $\$ 16,500$ to the Lake Tahoe Area Council for an engineering study of export methods for the north shore area of the lake. San Francisco Chronicle, June 24, 1964, p. 40, col. 8. 
the earliest possible date. ${ }^{258}$ While local agencies have a strong argument for financial aid from state and federal agencies for exporting solely to preserve the lake's clarity, dilatory attempts to forestall export are not the proper way to seek such economic assistance. Direct requests for financial aid by the public utility concerned is a sounder alternative. ${ }^{259}$

Pollution of basin waters and export of sewage effluent have been subjects of considerable interest to the interstate compact commission since shortly after the inception of negotiations. ${ }^{260}$ Two sections of article 8 of the proposed compact draft are directed toward the pollution problem. Section 7 of that article provides that the waters of the lake and its tributaries shall be maintained at a quality level suitable for maintenance of fisliery resources, for recreational use, and as a source of domestic water supply without treatment other than simple chlorination. The direct discharge of sewage or sewage effluent into the lake or its tributaries is prohibited unless the permanent commission determines that sucl discharge would not impair the prescribed quality levels. Primary responsibility for maintenance of water quality standards is left to the states. However, upon complaint by an appropriate state or local water pollution or public health agency, the commission is required to investigate and recommend corrective action. If the recommendation is not heeded, the commission must hold a hearing with notice to appropriate

258 Even assuming no further dispute over an export route, export by the fall of 1965 will be difficult to achieve. Within slightly over one year, legal and financial arrangements for the pipeline would have to be concluded, associated facilities such as pumps installed or constructed, and the pipeline itself laid across rugged terrain where work would be difficult in winter months. Installation of a sewer pipeline for the utility district in progress during January of 1964 was impeded by bad weatler, frozen ground, and frequent machine breakdowns. Tahoe Daily Tribune, Jan. 3, 1964, p. 1, col. 5.

250 Not only has $\$ 270,000$ in Public Health Service grants been made to the South Taloe Public Utility District for its tertiary treatment plant, but the California legislature recently approved a bill making a $\$ 1.8$ million low interest loan available to the district. See Lake Tahoe Area Council, Lake Tahoe, April 15, 1964, p. 2, col. 2. Nevada has over $\$ 1$ million in unallocated Public Health Service funds may be used to finance up to $40 \%$ of Nevada's share of the project. Tahoe Daily Tribune, June 16, 1964, p. 1, col. 4. The Douglas County Improvement District has an application for a $\$ 105,000$ grant pending before the Federal Housing and Home Finance Administration to pay for surveys and plans of a sewage export route via Daggett Pass into the Carson Valley. Id., June 5, 1964, p. 1, col. 8. The possibility of additional state and federal aid remains.

200 See, e.g., Joint Compact Comm'n, Minutes of May 20, 1958, at 11. The Califorma and Nevada statutes creating the Interstate Compact Commission defined the commission's jurisdiction to encompass negotiation of a compact relating to the distribution and use of the waters of Lake Tahoe and three specified rivers. See note 149 supra. The commission has apparently assumed that sewage and pollution matters relate to the distribution and use of basin water and therefore are subject to negotiation. However, a Nevada legislator Las recently contended that the commission only has authority to allocate water and that sewage matters are beyond the jurisdiction of the compact. Taloe Daily Tribune, August 26, 1963, p. 1, col. 2 . 
parties and may issue orders directing correction of the polluting activity. Upon failure to comply, court action may be sought to enforce the order. ${ }^{261}$ It is questionable whether the commission has authority under the compact quahity standards to take any action where sewage effluent indirectly reaching the lake poses only an aesthetic threat rather than a hazard to drinking water, recreational use of water, or fishery resources.

Section 8 of article 8 declares that export of waste waters shall be under the exclusive jurisdiction of the commission, and that no export shall be made unless permission is first granted by the commission. The commission is required to permit export from the Lake Tahoe basin when necessary for the public health and welfare and protection of the quality of the waters of the basin and tributary streams. ${ }^{202}$ In determining whether export shall be authorized, permitted, or suspended, ${ }^{268}$ the commission must consider recommendations of appropriate state and local public health and water pollution agencies. Export cannot be permitted where the exported waste waters would affect the health and welfare of the receiving area's inhabitants.

Export of sewage effluent is particularly important as it bears on the interstate compact commission's water allocation to the Tahoe basin of 34,000 acre-feet per year. ${ }^{264}$ The allocation was made on the assumption that fifty percent of the water consumed in the basin would return to the

201 See Jornt Compact Coman's, Report of the Draftnig Comanitree 10-12 (1963). 262 The use of the conjunctive word "and" rather than the disjunctive word "or" seems unwise. One interpretation might be that export could never be allowed on acsthetic grounds alone, but that the public health and welfare must also be affected. Even if the clause is interpreted as requiring export when either the public bealth and welfare or the quality of the lake waters is threatened, it could be contended that the word "quality" refers to the quality standards defined in section 7. Under those standards, it is not clear whether the commission has authority under the compact to grant permission to export where the lake waters were subjected only to an aesthetic threat, such as change of color or clarity, and where the quality level was not impaired to the point that fisheries, domestic water, or use of water for recreational purposes was threatened. However, the commission's jurisdiction might be sustained by inference from the language of section 8 , which implies that while export must be permitted where there is a threat to the public health and welfare and to the quahity of basin waters, it may be permitted or denied in the discretion of the commission in other circumstances not involving such a threat. In addition, it is possible that the commission would act under the standards prescribed in section 7 on the basis that algae resulting from eutrophication would present a threat to recreational uses of the water. Nevertheless, the provision is sufficiently ambiguous to merit a second consideration by the compact commission. Those opposing export might argue that permission to export for aesthetic purposes alone is not within the commission's power; thus time-consuming hitigation would be required to settle the controversy.

283 Inclusion of the right to suspend export as a commission power has been criticized by W. W. White, Chief of the Nevada Bureau of Environmental Health, on the ground that it could prevent the sales of bonds for sewage treatment. Joint Compact Comm'n, Minutes of Jan. 10-11, 1963, at 19.

204 Sce note 161 stipra and accompanying text. 
lake in the form of sewage flow. ${ }^{265}$ Thus, if all 34,000 acre-feet were used within the basin, actual depletion of the lake would amount only to 17,000 acre-feet. If sewage effluent is exported from the basin, up to 17,000 acre-feet of water could be totally lost for downstream use. Downstream interests argued that they should be protected from water loss in the event of sewage export out of the basin, and all parties to the negotiations agreed that some method of compensation should be required. ${ }^{266}$ The provisions finally included in the compact draft prevent export unless the commission determines the amount of water to be exported and computes the corresponding reduction in water available to downstream users. If it is determined that export would result in greater water reduction to downstream users than that which would occur if the full allocation of 34,000 acre-feet were being diverted to the basin, the commission is required to impose terms and conditions to prevent the reduction. Thus, if export results in a net depletion of greater than 17,000 acre-feet, some method of compensation must be imposed by the commission. The compact provisions were intentionally made flexible to allow the downstream users to be compensated by pumping an appropriate amount of water from Lake Tahoe, by reducing the gross allocation of 34,000 acrefeet to the Tahoe basin, by requiring importation of replacement water by the exporter, or by some other method. ${ }^{267}$

An infirmity in the compact export provisions is that the commission cannot require export on its own initiative. Permission must not only be sought by an applicant for a permit, but permission will be denied unless certain conditions are met, including evidence that the applicant can finance replacement water. ${ }^{208}$ It is questionable wliether the responsibility for taking steps to protect the lake's aesthetic quahty should be placed solely on the applicant. Public utilities might understandably be reluctant to undertake the financial burdens of export, particularly if local bond issues appear unlikely to succeed. Since the commission can allow export only upon application, and since it is questionable whether the commission can even take action to prevent sewage disposal on basin land pre-

265 Joint Compact Comm'n, Minutes of Feb. 27-28, 1961, at 39; Lake Tahoe Area Council, Lake Tahoe, Feb. 29, 1964, p. 2, col. 2; Tahoe Daily Tribune, Aug. 12, 1963, p. 1, col. 7 ; see note 166 supra. The $50 \%$ return flow was not written into the compact terms, however.

266 See Joint Compact Comm'n, Minutes of Feb. 27-28, 1961, at 37-39; Minutes of April 17-18, 1961, at 18-19. A Nevada representative insisted that replacement of exported water should be required solely by pumping from Lake Tahoe $75 \%$ of the quantity of water exported. California opposed both the percentage and establishment of pumping as the sole method of compensation. The California view prevailed in the compact draft.

267 Joint Compact Comm'n, Minutes of July 16, 1961, attachment No. 3.

268 It was suggested during the negotiations that the permanent Tahoe basin residents should not be required to bear the full expense of export. Nevada seemed favorably dis- 
senting only an aesthetic threat to Lake Tahoe, ${ }^{260}$ the compact draft apparently leaves to the states the responsibility for requiring export. Thus far, export has only been recommended by the California and Nevada Governors with respect to the south shore area. It is not presently unlawful to dispose of sewage on basin lands. Other lake areas and communities are bikely to continue land disposal practices, particularly if such practices are less costly than export. Unless the respective states take strong action to require export, the commission may be powerless to protect the lake under the present compact terms. The compact should be amended to enable the commission to require export by local sewage agencies whether or not an application is made and when the sole reason is to protect the lake from aesthetic deterioration. In addition, the respective states should clearly recognize that the financial burden for export, undertaken to preserve the lake's aesthetic quality, should not be borne solely by the local taxpayers. Outright grants of funds to local pubhic utilities should be considered by the state legislatures. ${ }^{270}$ State financial assistance will help lessen the possibility of a refusal by local taxpayers to appropriate the money necessary for export. ${ }^{271}$ Delay, how-

posed to a contribution by downstream users and others to help defray the expense. See Joint Compact Comm'n, Minutes of Oct. 13, 1961, at 11-12. However, the compact draft requires the apphicant seeking export to bear all of the expense.

269 See note 262 supra.

270 While Cahifornia has made money available to the South Tahoe Public Utility District on a loan basis for construction of export facilities, and Nevada holds a sizable amount in Public Health Service funds which are available for the project, see note 259 supra, no grants have yet been made by the state. In addition to the initial costs of construction for export facilities, higher annnal maintenance and operating costs can be expected than would occur if export were not undertaken.

271 The likelihood of such refusal is not at all remote. In late 1962, voters at South Tahoe refused for the third tine to approve by the necessary two-thirds majority a general obhigation bond issue intended to provide funds for acquisition of sorely needed additional land and transport facilities for sewage disposal. The South Tahoe Public Utility District was at that time seeking to remove a cease and desist order issued by the Lahontan Regional Water Pollution Control Board resulting from over-flow of sewage effluent to lake tributary streams in 1961. See Lake Tahoe Area Council, Lake Tahoe, Sept. 30, 1962, p. 1, col. 1.

The Utility District has several alternative methods available to finance sewage export facilities. General obhigation bonds may be issued by public utility districts, but they are limited to $20 \%$ of the assessed valuation of the district. CAL. PUB. UTII. CODE $\$ 16573$. These bonds are limited to a maximum term of 75 years and a maximum annual interest rate of $6 \%$. Issuance requires approval of a two-thirds majority of those voting in the bond election. General obhigation bonds are advantageous because they are backed by the total assets of the issuing agency. They are therefore attractive investments and normally carry low interest rates. See South Tamoe Pubic Utzity Distruct, South Tamoe Sewerage Survey 131 (1959). The 20\% limitation can be exceeded to finance sewage disposal facilities by means of a bond issue, but the indebtedness must be repaid within 40 years. CaL. PuB. UTr.. CODE $\S 16574$. The total assessed valuation of property at South Tahoe is estimated to reach about $\$ 21.5$ million in 1965. SOUTH TAHOE PUBLIC UTHITY Districr, stepra at 132.

Issuance of revenue bonds is a second alternative available. Sewer revenue bonds may 
ever, in arranging financing will contribute to the impairment of the lake's clarity.

There have been recent indications that the basic 34,000 acre-feet allocation might be reopened for further negotiation in hight of sewage export considerations. ${ }^{222}$ Further negotiations to amend the already settled gross allocation, the product of lengthy debate and a dehicate weighing of interests, might seriously jeopardize the commission's progress and postpone indefinitely the conclusion of the compact.

It is particularly unfortunate that methods to protect the lake from the threat of deterioration which would not affect the water allocation to the Tahoe basin or the rights of the Truckee users have not been further investigated. Removal by the Truckee River might still be accomplished if downstream users could be convinced that no public health threat is involved. Clear evidence that effluent would meet drinking water standards has not yet been presented by the South Tahoe Public Utility District. Supporting data is a prerequisite to any attempts at informing the pubhic of the safety and purity of the effluent. If highly treated water meets drinking water standards, a program of public education might help overcome resistance to removal via the Truckee. ${ }^{273}$ It seems partic-

be issued under CaL. Heatre \& SAFETY CODE $\$ \$ 4950-5072$ without limit by the governing body of the district. However, if $15 \%$ of the affected property owners object by signed petitions, the issuance of the bonds is subject to a majority vote of the district's property owners. Cal. Hearte \& Safety Code \$\$ 4975-79; Soutr Tamoe Public Utinity District, supra at 132. Revenue bonds may also be issued under the Revenue Bond Law of 1941, CAL. Gov'x. CODE $\S \S 54300-672$. The issue must be authorized by a majority of the voters participating in the election. CaI. Gov'T CODE \& 54386. Revenue bonds issued under either the Revenue Bond Law or the terms of the Health \& Safety Code are hmited to a maximum term of 40 years and a maximum interest rate of $6 \%$. See Cal. Healtr \& Safety Code $\S \S 4988,4990$; CAL. Gov'T CODE $\$ \S 54400,54402$. Revenue bonds are not as readily marketable as general obligation bonds because they are backed only by revenue derived from the users of the facility they finance. South TaHoE PUBLIC UTIITT DisTrict, supra at 132.

Finally, financing may be accomplished through one of several available special assessment proceedings, by which the improvements are paid for by special assessment against the benefited properties. This financial method is normally employed only as a last resort by local agencies, since it is more costly than financing by general obhgation or revenue bonds, and calls for repayment within a short period of time. Ibid.

Should voters refuse approval of a bond issue to finance expensive export facilities by general obligation or revenue bonds, the utility district may be forced to finance the system with the more expensive special assessment procedure. Financing export in the face of voter disapproval does not seem to present a desirable alternative for the utility district.

Exhausting the avenues available to finance export may be time-consuming sliould voters resist approval of bond issues. To prevent possible needless delay, and to ameliorate the inequity of requiring local taxpayers to finance the full cost of export undertaken in the public interest, state grants are highly desirable.

272 See Joint Compact Comm'n, Minutes of Oct. 10, 1963, at 14; Minutes of Feb. 26, 1964, at 7; Lake Tahoe Area Council, Lake Talsoe, Feb. 29, 1964, p. 2, cols. 2-3; Tahoe Daily Tribune, Aug. 12, 1963, p. 1, col. 6.

273 An additional argument for removal to the Truckee in the way of a safety feature 
ularly harsh for Lake Tahoe taxpayers to be required to pay for import of replacement water for Truckee River users who have themselves produced the need for replacement. Preserving Lake Tahoe's clarity is an obligation which should be shared by all and should not be an onus borne by a particular area or group of citizens. If Truckee River users forbid discharge of pure and safe water into the river, it seems manifestly unjust that these same users should deniand compensating water when the effluent is exported elsewhere, particularly where these users do not share in the cost of either export or import.

An additional alternative which should be further considered was recently suggested in an editorial of the Tahoe Daily Tribune. ${ }^{274}$ It was proposed that the effluent be impounded at a suitable site in the Tahoe basin and seeded with fish, plankton, and algae to help purge the water of nitrates and phosphates. Investigation might disclose the feasibility of developing a reservoir which would not pose a threat to the lake through nutrient-rich seepage.

Even if successful export or removal of sewage from the south shore of the lake is accomplished, the pollution threat to Lake Tahoe will not be eradicated. It is estimated that ninety percent of all Lake Tahoe residents rely on septic tanks to dispose of sewage, ${ }^{275}$ and even in the area serviced by the South Tahoe Public Utility District only twenty percent of the existing development is tied into the established collection system. ${ }^{278}$ Septic tank effluent presents as nuch of a pollution problen to the lake as does a large treatment plant. ${ }^{277}$ Tank leakage is common, and many of the tanks are close enough to the lake shore to permit seep-

is the great dilution which would occur when the effluent is combined with normal river flow. The mean annual natural flow of the Truckee River at the California-Nevada border including Lake Tahoe outflow during the 30 year period 1922-1952 was 503,400 acre-feet. JonNT

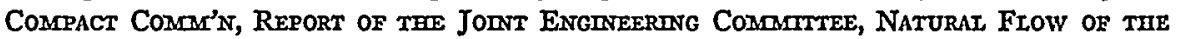
Trucken Rrver 16 (1957). The volume of Lake Tahoe sewage for the year 1962 was estimated to be 2,900 acre-feet, and this volume is expected to increase to 22,000 acre-feet in 2010. Comprrenenstve Study 93; Tahoe Daily Tribune, June 4, 1964, p. 1, col. 8. Thus, the present volume of effluent would be just over $0.5 \%$ of the total volume of water flowing at the state line, increasing to about $4 \%$ in 2010 . Dilution available by disposal of effluent into the Truckee nakes this method of disposal preferable to use of undiluted effluent by basin residents. While it has not been suggested that the effluent be retained in the basin for re-use as drinking water, this night be feasible if the water were of drinking water quality and if a nethod of holding the effluent in the basin without any possibihity of it reaching the lake were developed. If the choice is to have the basin residents drink undiluted effuent of drinking water quahty or to have Truckee River residents use the same water in a mixture of 0.5 to 4 parts effluent per hundred parts of river water, the latter seenis preferable.

274 Tahoe Daily Tribune, May 8, 1964, p. 1, col. 6.

275 Id., Sept. 30, 1963, p. 1, col. 1.

276 Joint Compact Coinm'n, Minutes of Jan. 10-11, 1963, at 21.

277 Letter from J. T. Leggett, Executive Director, Lahontan Regional Water Pollution Control Board, to authors, Feb. 13, 1964. 
age of raw sewage wastes directly into the lake. ${ }^{278}$ Septic tanks must be periodically pumped and waste matter disposed of. Septic tank dumpings have in the past been processed by the South Tahoe Public Utility District, where overloaded treatment facilities have caused breakdowns, ${ }^{279}$ or have been disposed of by discharge directly on land within the basin. ${ }^{280}$ Large areas around the lake are presently outside the limits of existing public utility districts and must rely solely on septic tanks. ${ }^{281}$ A 1963 pollution report by Engineering-Science recommended a basinwide collection system costing an estimated twenty-one million dollars for the capacity needed until 1980, with an additional seventeen million dollars required to handle basin needs through year $2010 .{ }^{282}$ The Lahontan Regional Water Pollution Control Board recently indicated that consideration of a single district to collect sewage for the entire basin has been abandoned, ${ }^{283}$ since there are large areas on the east and west shores of the lake that are undeveloped. Thus, an outfall system through these areas would collect no sewage and be extremely expensive. Unincorported areas must either form their own districts to collect and treat sewage or join existing districts. Current indications are that two export systems will eventually result —one at the south end and the other at the north end of the lake serving all adjacent areas. ${ }^{284}$ As development of the

278 Tahoe Daily Tribune, Sept. 30, 1963, p. 1, col. 1.

279 Id., p. 1, col. 3; Sept. 11, 1963, p. 1, col. 1; Oct. 4, 1963, p. 1, col. 5; Oct. 8, 1963, p. 1, col. 2. Septic tank bacteria are an underground type which counteract the action of fresh air bacteria that work to purify sewage in land disposal. Concentration of septic tank sludge has threatened the breakdown of the South Tahoe district's treatment plant, and septic tank dumpings were halted in the fall of 1963 until the California Department of Public Health ordered the district to accept further tank disposals.

280 The El Dorado county dump at Meyers was used for septic tank dumping until 1960, when it was closed for that purpose hecause of a health and pollution hazard. The El Dorado county health departmeut requested the Umited States Forest Service to again accept raw sewage at the dump in the fall of 1963, hut the request was refused on the ground that it was not in the public interest to dispose of raw sewage on any land in the Tahoe Basin. Tahoe Daily Tribune, Sept. 30, 1963, p. 1, col. 1.

281 For example, there is a large area without sewers, relying solely on septic tanks, lying between the North Tahoe and Tahoe City Public Utility Districts. Letter from J. T. Leggett, supra note 277.

282 Tahoe Daily Tribune, June 17, 1963, p. 1, col. 5. The outlet for the collection system was assumed by the scientists for cost purposes to be the Truckee River.

283 Letter from J. T. Leggett, supra note 277.

$284 \mathrm{Ibid}$. Some authorities favor expansion of existing districts to provide for collection, treatment and export facilities for all areas without sewers. If new districts are formed, collection and treatment would probably be performed by them, but it would not be economical or feasible for each unit to export by its own facilities. A contractual arrangement with the northern or southern utility district having control of the export facilities for that end of the lake is one suggested approach. Ibid.

Placer County is negotiating at the present time for an engineering study of the north shore area of the lake. It is anticipated that the North Taboe and Taloe City Public Utility 
north shore increases, the threat of pollution in that area will likewise arise. ${ }^{285}$ State and local agencies should do all in their power to facilitate expansion of collection and treatment facilities around the lake and to liasten construction of an export system serving the north shore. The basin must be protected by these agencies, since ratification of the interstate compact creating a bi-state body with continuing jurisdiction over pollution and export matters may not result for some time.

\section{CONCLUSION}

Lake Tahoe does not lack agencies and groups seeking resolution of the area's problems. It appears, however, that despite the profusion of parties interested in the future of the basin, serious deficiencies in respect to both means and objectives have been manifested. With the exception of the privately organized Lake Tahoe Area Council, no agency or group has consistently adhered to a program of preserving the plysical attributes of the lake area.

In the area of land use regulation, the present county zoning ordinances and their enforcement have proved inadequate to insure an order and ecologically sound pattern of development. The unwillingness of the five counties to subordinate sectarian economic interests in rapid growth and development of the lake basin to the national interest in preserving the lake as a natural resource has been manifested not only in deficiencies of the present zoning laws, but also in frequent departures from existing controls. Responsibility for inadequacies in approach lies partly with local government operating in county seats geographically and economically removed from the Lake Tahoe basin and partly with the permanent residents. Neither group has recognized that Tahoe must be protected with restrictions on private enterprise in the interest of

Districts will combine their wastes in an outfall and pump north to the Martis Valley area. lbid. Effluent received in the Martis Valley would apparently flow back to the Truckec River in some amount. See Tahoe Daily Tribune, Aug. 28, 1963, p. 1, col. 1. Thus, the compact water allocation would be less seriously affected by this export routc.

285 The north shore area is not nearly as highly developed as the south shore, but population in the north is predicted to be at least 150,000 in the year 2010. CompreHENSTVE STudy Figs. 6-7. Incline Village near Crystal Bay, newly constructed by a private company, can be expected to develop rapidly. It is interesting to note that the developers originally planned to pump sewage from the village into the Washoe Valley. See Lake Tahoe Aren Council, Lake Tahoe, May 31, 1961, p. 4, col. 4. This plan was abandoned in favor of underground disposal within the basin, for which a permit was granted by the Nevada State Department of Health. A sanitary engineer from the Cahforma Institute of Technology, retained by the Lake Tahoe Area Council, predicted that Incline Village land disposal operations a few thousand feet from the lake shore would fail in five to ten years. The area council expressed concern to the Nevada Health Department over possible pollution of Lake Tahoe from this system. Lake Tahoe Area Council, Lake Tahoe, Feb. 28, 1962, p. 1, col. 2. 
conservation. Strong limitations are as appropriate at Tahoe as in any national park. A thriving metropolis characterized by towering skyscrapers and blazing neon signs is no more appropriate at Tahoe than at Crater Lake, Yellowstone, Yosemite, or other of the nation's exceptional plyysical assets.

The recently formulated Tahoe Regional Planning Commission offers grounds for optimism with respect to sound area developnient. While the master plan proposed by this agency provides a firn starting point for regulation of Lake Tahoe's future growth, effectuation of the plan's goals requires an adequate legal framework. Assuming the commission is able to procure adoption of a uniform zoning ordinance to implement the plan, the question remains whether the law will be uniformly and strictly applied. The past pattern of non-conforming uses and the hiberal granting of variances must not be repeated if the plan is to succeed, nor should amendment of the uniform ordinance readily be obtainable by individual counties. Furthermore, the full and active cooperation of the California and Nevada Governors, legislatures, and state agencies must be obtained. The inability to achieve such cooperation was recently underscored by the failure of the Nevada legislature to adopt the proposed bi-state park on the lake's east shore. While the proposed Nevada state park is commendable, it falls short of the sizeable park contemplated by regional planners. In addition, the plan's intent to preserve the west shore of the lake from the blight of a multi-laned highway is threatened by the California Division of Highways. It can only be concluded that voluntary adoption of the regional plan for Lake Tahoe by all agencies is far from a final answer.

In regard to the water problem, the dehicate balance of interests achieved in the interstate compact negotiations to date should not be upset by contentions adamantly put forward by parochial interests. The gross allocation of water made under the compact slould not be reopened for discussion merely because downstream users desire a greater amount. The United States Government should accept the compact allocation made by the states without protest, even though its claimed riglits are affected. To insist upon changes in the compact terms, which federal agency representatives have hinted they miglit $\mathrm{do},{ }^{286}$ would require that the compact be returned to the commission for further negotiations. Any change in provisions miglit seriously jeopardize the entire compact, and would at the very least extend the period of time until final adoption.

Althougl the compact negotiations have entered their ninth year, it may be ill-advised for the states to insist upon conpletion of the compact

286 See Compact Comm'n, Minutes of Aug. 4-5, 1959, at 10; Minutes of Sept. 2, 1959, at 5-6. 
drafting by an arbitrarily established date. The future workability of the compact calls for careful drafting and close scrutiny of compact terms by the commission members. The proper time for lieavy pressure and strenuous effort to complete the compact is after the compact draft is recommended for adoption by the state compact commissions.

The pollution problem at Lake Tahoe has reached the stage where further dilatory measures will cause serious results. The deadline of fall 1965, imposed by Governors Brown and Sawyer for the removal of sewage from the basin, should be met with strict adherence. In addition, every effort should be made to select the location for receipt of effluent which will least affect the water allocation agreed upon in the interstate compact. While effluent of drinking water quality endangers the purity of Lake Tahoe, it offers no threat to the public health; therefore, removal of the effluent via the Truckee River, as recommended by the panel of scientists who recently completed a comprehensive study of the problem, ${ }^{287}$ seems warranted upon an unequivocal showing by the South Tahoe Public Utility District that treated effluent does in fact meet drinking water standards of the Umited States Public Health Service. Not only is the Truckee the closest river to Lake Tahoe and as economical a choice for effluent disposal as other suggested export routes, ${ }^{288}$ but removal to that stream would preserve the water allocation of the compact. Opposition of downstream users, while understandable, could be overcome by a thorough public relations effort aimed at explaining the treatment process and assuaging fears that any ill effects would result from removal to the Truckee. The very least that is called for is a concerted effort by both states to preserve the accomphishments of the interstate compact commission. If effluent is exported into the Carson Valley in Nevada, a system of exchange water credit should be arranged. Since it is the downstream users who would force necessary export by a route which would reduce the Truckee River water supply, it seems inequitable that hittoral lake dwellers should bear the full economic burden. To import water at great cost while exporting water meeting drinking water standards of the Umited States Public Health Service seems unnecessary and unwise. Those who force this alternative should bear a part, and possibly the major part, of the cost if the Truckee River flow is reduced as a result.

Complete elimination of the pollution danger to Lake Tahoe requires a sewage collection system covering all basin areas. The best and most economical alternative may be two collection systems-one operating at

287 See note 223 supra and accompanying text.

288 CoMrrehenstve Study 119. 
the southern and another at the northern end of the lake. Seepage from septic tanks, and preferably the tanks themselves, should be eliminated. State pollution control boards and state and county health agencies should insist that steps be initiated toward construction of an adequate collection system; building permits should be denied for construction which cannot tie plumbing into a system resulting in removal of sewage from the basin. ${ }^{289}$ The residents of the Lake Tahoe basin should assume the responsibility for creation of the basin-wide treatment and collection system through sewer bond issues. The desirability, however, of state and federal assistance to help eliminate the over-all pollution threat to the lake is self-evident. State or federal funds should be created specifically to aid in building export pipehnes and, if necessary, in construction of necessary import facihties to provide replacement water.

The California-Nevada Interstate Compact Commission, which has apparently completed negotiations with respect to the water and pollution problems of the Lake Tahoe basin, should review the compact draft and consider an amendment which would clarify the water quality and export provisions. The permanent commission should be empowered to act to prevent aesthetic threats to waters of the lake and should be empowered to require export for protection of the lake without an application being made by a local agency.

Finally, the compact conumission might profitably be employed to deal with Tahoe problems in a broader framework. For example, including in the compact a uniform zoming ordinance implementing the proposals of the regional planming commission could insure the uniform and strict apphication of the ordinance. Amendment of the compact solely in response to sectarian pressures would be extremely difficult. Furthermore, provisions might be included which required the respective state highway departments to submit all proposed highway routes to the commission for approval. In approving routes, the commission would consider the harmony of the route with the regional plan and could solicit opinions concerning the route from respective state agencies, such as the Divisions of Beaches and Parks, and from local residents and other interested parties. Of course, in order to expand the scope of the compact negotiations to achieve these ends, the enabling statutes of the respective states and the federal government must be amended. The hikehhood that

289 The El Dorado County engineer recently demanded a moratorium on construction of new subdivisions within the Lake Tahoe basin because of inadequate drainage, water supply, sewage and garbage disposal facilities. Tahoe Daily Tribune, May 26, 1964, p. 1, col. 6. Halting further construction and development by denying building permits is a powerful measure available to the counties which can help to impress the local residents of the serious need for adequate collection and export facilities. 
an expanded interstate compact ${ }^{290}$ will further preservation of the Lake Tahoe basin as a unique resource clearly shows the desirability of this new step.

\title{
Carl R. Pagter
}

Cameron W. Wolfe, Jr.

\begin{abstract}
200 An alternative to an expanded interstate compact is the establishment of an autonomous federal agency similar in type to the Tennessee Valley Authority for overall regional administration of the Lake Tahoe basin. See generally HufFucar, IrRIGATION Developarent and Public Water Policy 166-73 (1953); Zimomermann and Wendell, The Interstate Compact SINCE 1925, at 112-21 (1951); Robinson, Voluntary Regionalism in the Control of Water Resources, 207 Annals 116-23 (1940).
\end{abstract}

Reprints of this Comment are available from the offices of the CALIFORNIA LaW REVIEW. 